\title{
Effects of seismic anisotropy and geological characteristics on the kinematics of the neighboring Jiufengershan and Hungtsaiping landslides during Chi-Chi earthquake
}

\author{
Jia-Jyun Dong ${ }^{a, *}$, Wang-Ru Lee ${ }^{\mathrm{a}}$, Ming-Lang Lin ${ }^{\mathrm{b}}$, An-Bin Huang ${ }^{\mathrm{c}}$, Yen-Liang Lee ${ }^{\mathrm{d}}$ \\ a Institute of Applied Geology, National Central University, No.300, Jungda Rd., Jungli, Taoyuan, Taiwan 320, ROC \\ ${ }^{\mathrm{b}}$ Department of Civil Engineering, National Taiwan University, Taipei, Taiwan, ROC \\ ${ }^{\mathrm{c}}$ Department of Civil Engineering, National Chiao Tung University, Hsinchu, Taiwan, ROC \\ ${ }^{\mathrm{d}}$ Central Geological Survey, MOEA, Taiwan, ROC
}

\begin{abstract}
The Chi-Chi earthquake (Mw=7.6) of September 21, 1999 triggered many landslides in central Taiwan. Two of these landslides, Hungtsaiping (HTP) and Jiufengershan (JFES) were situated as close as $2 \mathrm{~km}$ from each other but had significant differences in their kinematics. JFES landslide was a catastrophic rockslide-avalanche and the HTP landslide was relatively slow-moving. The authors conducted a study to explore the reasons for such differences. Factors such as the characteristics of strong ground motion, sliding direction of landslide, and friction angle of the sliding surface were considered in the study. An analysis of 12 strong-motion records collected in the study area showed that the distribution of horizontal pseudostatic coefficients, earthquake energy ratio and permanent sliding-block displacements (Newmark displacement) were anisotropic with their predominant direction mostly in the E/W-ESE/WNW trending. This direction is perpendicular to the axis of the main geological structures of the studied area. The computed Newmark displacement in the sliding direction of the JFES landslide is larger (44\%) than that of the HTP landslide with sliding surface inclination of $21^{\circ}$ and friction angle of $28^{\circ}$ We can conclude that the seismic anisotropy and the corresponding sliding direction are important contributing factors to the kinematics of studied landslides. The back-calculated friction angle of the sliding surface that corresponds to a critical Newmark displacement for the JFES landslide is about $3.5^{\circ}$ higher than that of HTP landslide. The material (colluvium) on the sliding surface in HTP should be less velocity-dependent than that of the JFES landslide (rock) according to the back calculations. The importance of seismic anisotropy, sliding direction, and mechanical properties of sliding surface on the kinematics of deep-seated landslides is demonstrated.
\end{abstract}

(C) 2007 Elsevier B.V. All rights reserved.

Keywords: Earthquake; Seismic anisotropy; Landslide; Colluvium; Newmark method; Velocity-dependent friction law

\section{Introduction}

Because of the nature of tectonic movements that created the island of Taiwan, most of the geological structures in this region are aligned in the NS to NE-SW directions. The main ridges of the mountain ranges created by tectonic movements are roughly parallel to these NS to NE-SW trending geological structures. The Chi-Chi earthquake $(\mathrm{Mw}=7.6)$ of September 21, 1999

\footnotetext{
* Corresponding author. No.300, Jungda Rd., Jungli, Taoyuan, Taiwan 320, ROC. Tel./fax: +88634224114 .

E-mail address: jjdong@geo.ncu.edu.tw (J.-J. Dong).
}

triggered many landslides in central Taiwan (Hung, 2000; Liao, 2000; Huang et al., 2001; Khazai and Sitar, 2003; Lin and Tung, 2003; Lin et al., 2003; Wang et al., 2003a,b). For Chi-Chi earthquake, the EW components of the horizontal peak ground accelerations (PGA) are stronger than those in the NS direction according to most of the strong-motion records (Shin, 2000). The major principal direction of PGA is almost perpendicular to the NS trending Chelungpu fault (Loh et al., 2000). Lin and Tung (2003) suggested that the thrusting process of the Chelungpu fault may have played an important role in the orientation of the Chi-Chi earthquake-induced landslides. It is generally believed that the intensity of ground motion, 
geological and morphological factors, as well as material properties, determine the occurrence and kinematics of seismically triggered landslides (Keefer, 1984; Keefer, 2000; Parise and Jibson, 2000; Helmstetter et al., 2004). In addition to its wealth of strong-motion records, the Chi-Chi earthquake triggered a number of large landslides. These well documented events offered a unique opportunity to evaluate the above described factors and their relationships to the characteristics of landslides.

Jiufengershan (JFES) and Hungtsaiping (HTP) are two of the most noticeable large and deep-seated landslides induced by Chi-Chi earthquake (Wang et al., 2003a; Lee et al., 2004; Wei and Lee, 2006). The closest distance between these two landslides is $2 \mathrm{~km}$. Fig. 1 is an aerial photo of the JFES and HTP landslides after Chi-Chi earthquake. The distance and velocity of the sliding block were large enough to characterize the JFES landslide as a catastrophic rockslide-avalanche. On the other hand, most of the displaced areas in the HTP landslide were only slightly disturbed with relatively modest displacement. The material within the failure zone at HTP is mostly colluvium. The differences in kinematics observed in these two landslides triggered by the same earthquake motivated the research.

The seismic record of the Chi-Chi earthquake (Lee et al., 1999, 2001a) and earlier studies associated with this earthquake (a) The HTP landslide

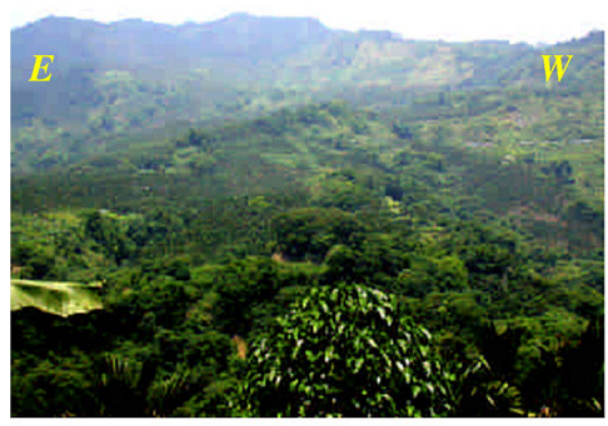

(b) The JFES landslide

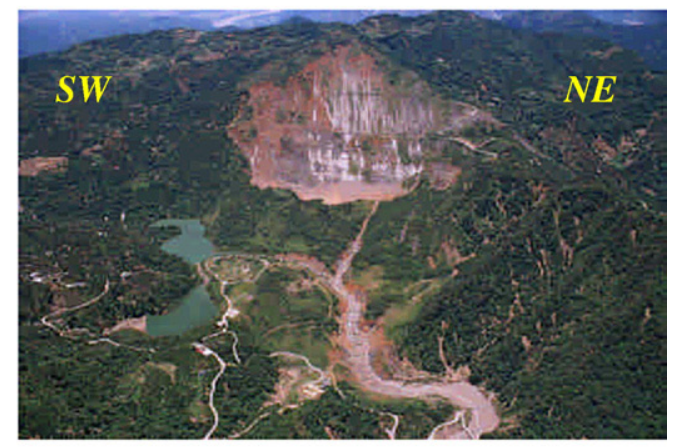

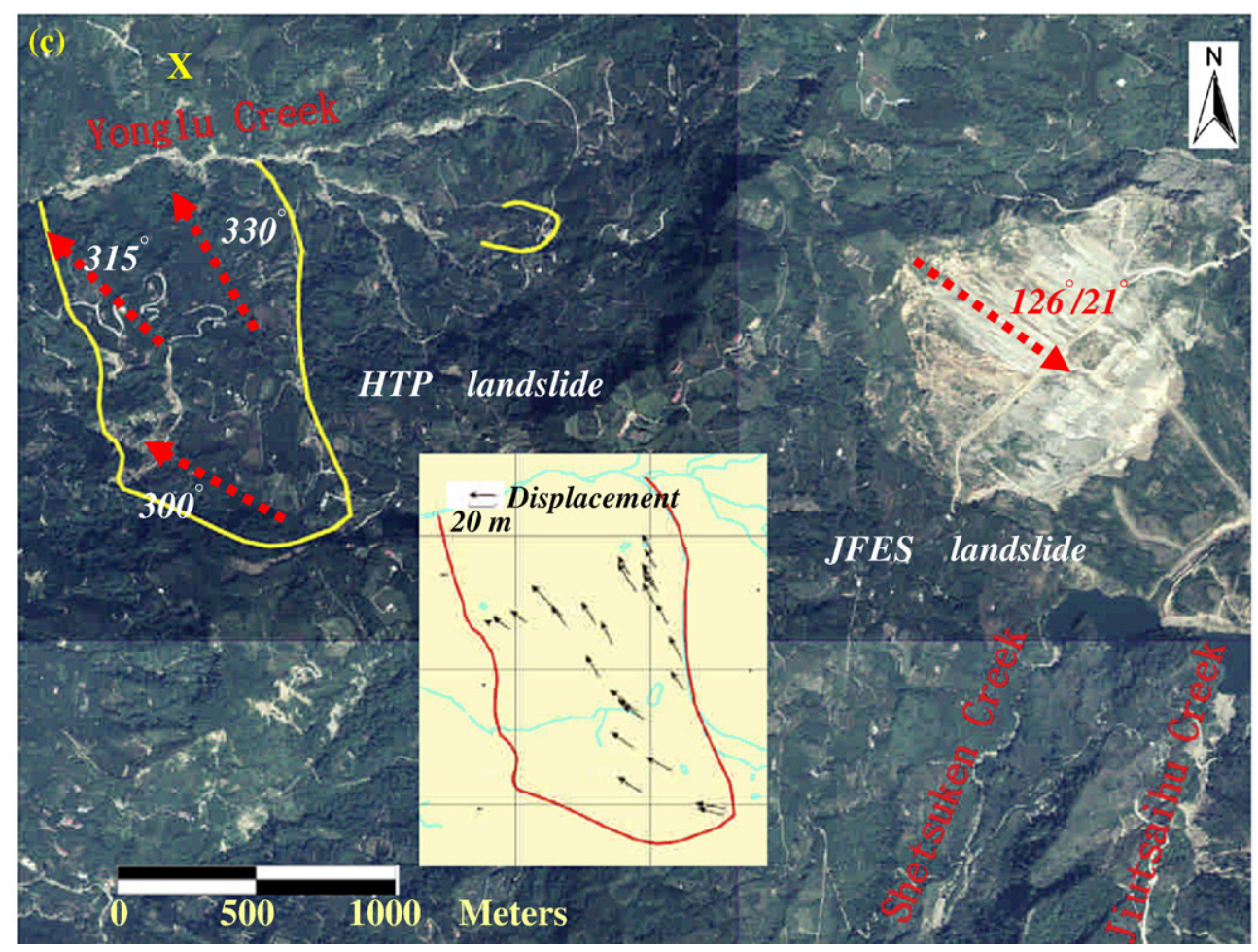

Fig. 1. (a) Photo of the HTP landslide after the Chi-Chi earthquake. View southward from point X (upper left corner of (c)) at north side of Yonglu Creek. (b) Photo of the JFES landslide. (c) The aerial photo of the JFES landslide (east slope; right side) and HTP landslide (west slope; left side). Displaced materials of the JFES catastrophic rockslide-avalanche followed the dip direction and ran out more than $1000 \mathrm{~m}$ southeastward and dammed two creeks (shown in (b)). The HTP landslide was less violent and the sliding direction was northwest. Most of the displaced areas of HTP landslide were only slightly disturbed (shown in (a)). The horizontal surface displacement vectors and the boundary of the HTP landslide (as shown in (c)) were identified by digital aerial photogrametry based on the aerial photos taken before and after the Chi-Chi earthquake (Lee et al., 2004). The displacement vectors can be further divided into three groups, trend $330^{\circ}, 315^{\circ}$, and $300^{\circ}$. 
provided abundant background information to explore the possible factors that govern the kinematics of the two large earthquake-induced landslides. The authors evaluated the characteristics of the strong-motion records using dimensionless indices that include direction-dependent (1) horizontal pseudostatic coefficients and (2) earthquake energy ratios. A total of

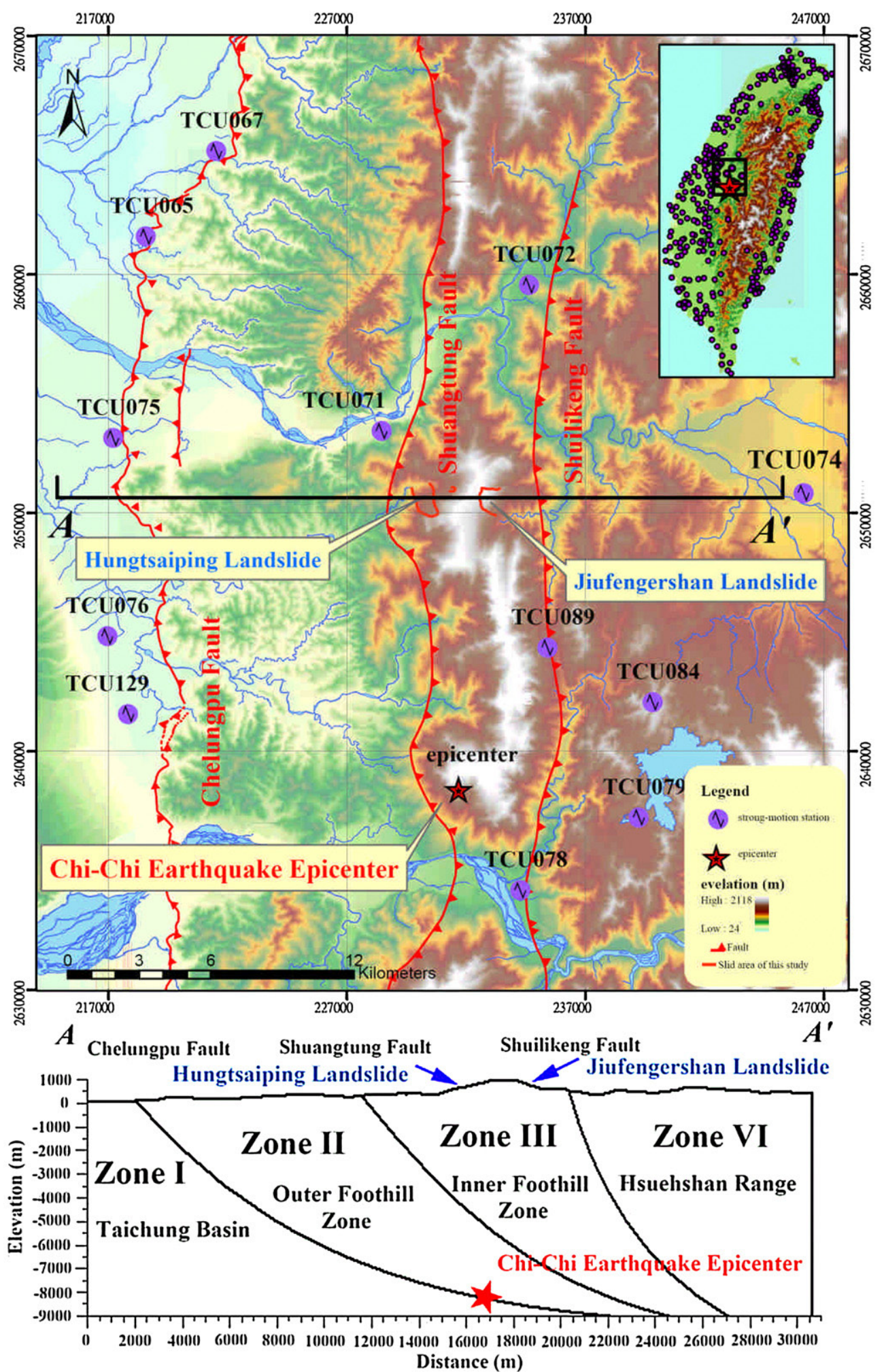

Fig. 2. Epicenter of the Chi-Chi earthquake, locations of studied landslides, strong-motion stations, and major faults in central-western Taiwan. The Chelungpu fault is ruptured during the Chi-Chi earthquake. Cross-section boundaries. A-A' shows Zones I-IV and their boundaries. 
twelve strong-motion stations surrounding the studied landslides were selected. These stations were distributed in four different geological zones (characteristics of the geological zones will be described later). Evaluation of the strong-motion records reveals the relationships between seismic anisotropy and the geological background. A modified Newmark's (1965) sliding-block method (Huang et al., 2001) was used to compute the permanent sliding-block displacements (Newmark displacement) in different directions. The effects of seismic anisotropy on Newmark displacements with different sliding directions were then evaluated quantitatively. Finally, a velocity-dependent Dieterich-Ruina friction law (Dieterich, 1979; Ruina, 1983; Beeler et al., 1994; Scholz, 1998) was incorporated into the modified sliding-block method. The mechanical characteristics of sliding materials on the kinematics of the two landslides are discussed. The paper provides details of the analyses performed, summarizes our findings and discusses the implications on the relationships among geological structures, characteristics of strong ground motion, material properties and kinematics of landslides.

\section{Geological setting of the studied areas}

In central-western Taiwan, there are three major faults distributed from east to west: the Shuilikeng, Shuangtung, and Chelungpu faults which strike N-S with an eastward dip (Fig. 2). Four zones including: (I) Taichung Basin (II) Outer Foothill zone, (III) Inner Foothill zone, and (IV) Hsuehshan Range, are separated by the above three faults. EoceneOligocene rocks are thrusting over Miocene rocks along the Shuilikeng fault and Miocene rocks are thrusting over PliocenePleistocene rocks along the Shuangtung fault. PliocenePleistocene rocks are thrusting over the younger alluvial and fluvial deposits of the Taichung basin along the Chelungpu fault which was reactivated during the Chi-Chi earthquake in 1999. The Chelungpu fault is moving mainly westward at the south end and gradually turning to northwest northward along the fault (Yu et al., 2001).

The subject landslides are located between the Shuilikeng and Shuangtung faults (Zone III) which are mostly underlain by Miocene sedimentary rocks. The JFES landslide, one of the well known large landslides induced by the Chi-Chi earthquake, is located $15 \mathrm{~km}$ northeast of the epicenter (Fig. 2). An estimated volume of $50 \times 10^{6} \mathrm{~m}^{3}$ of displaced material buried 39 people and dammed two creeks. A slope area of 102 ha slipped and the deposit covered an area of 92.5 ha (Wang et al., 2003a). The JFES landslide can be categorized as a catastrophic dip slope rockslide-avalanche. The sliding direction $\left(126^{\circ} / 21^{\circ}\right)$ is identical to the dip direction of the bedding plane (Chang et al., 2005a). The slide material displaced more than $1000 \mathrm{~m}$ southeastward along a weak bedding plane associated with flexural slip folding (Wang et al., 2003a). The velocity of the sliding block was calculated to have reached a peak value of $80 \mathrm{~m} / \mathrm{s}$ using a block-on-slope thermo-mechanical model (Chang et al., 2005b) analysis.

The HTP landslide, a less noticeable landslide triggered by Chi-Chi earthquake, is located west of JFES (Fig. 1). Most of the displaced area was only slightly disturbed by the HTP landslide. The morphological features at HTP landslide include a crown, tension cracks, main scarp, secondary scarps, depression, hummocky ground surface, and an accumulation zone at the toe. The displaced area of 100 ha and surface displacement vectors of the HTP landslide were identified by digital aerial photogrametry (Lee et al., 2004). The constitutive material of the HTP landslide is inferred to be colluvial deposits from morphological evidence. The estimated maximum horizontal ground displacement is $32.0 \mathrm{~m}$ (Lee et al., 2004; Fig. 1). The sliding velocity and run out distance of the HTP landslide are far less than those of the JFES landslide.

Fig. 3 shows the general geological map of the studied area (modified from Huang et al., 2000). The strata exposed in this area, beginning with the oldest, are Tanliaoti Shale $(\mathrm{Tl})$, Shihmen Formation (Sm), Changhukeng Shale (Ch), Shenkeng Sandstone (Sk) and Kueichulin Formation (Kc). The Tanliaoti Shale (Tl) consists mainly of massive grey shale with thinbedded sandstone. The Shihmen Formation (Sm) is composed of 3 thick sandstone layers with dark grey shale or sandstone/ shale interbed and usually form cliff. The Tanliaoti Shale and the Shihmen Formation are found in the downslope and upslope of the HTP landslide area, respectively. The Changhukeng Shale $(\mathrm{Ch})$ is composed of dark grey marine shale with subordinate sandstone. The $\mathrm{Ch}$ is distinguished by its massive shale bedding with ripples where it contains interbeds of siltstone or sandstone. The Shenkeng Sandstone (Sk) is composed of massive sandstone with dark grey shale. The Tsukeng anticline, trending NE-SW, is the major fold structure in the area. The JFES and HTP landslides are respectively situated on the eastern and western limbs of this anticline. The toes of the JFES and HTP landslides are cut by the Taanshan and Tingshuiku faults, respectively.

Both of the studied landslides are located in the same geological zone (Zone III). The elevation of the landslides is between 500 and $1000 \mathrm{~m}$. An NE-SW trending ridge and axis of an anticline separates the two landslides. The studied area is underlain by thick Miocene massive shale with thin-bedded siltstone and sandstone. Since the two landslides are very close to each other, the influence of strong ground motion induced by ChiChi earthquake should also be similar. As stated previously, the JFES landslide was categorized as a catastrophic dip slope rockslide-avalanche where massive Shenkeng Sandstone (Sk) slided along a bedding plane in Changhukeng Shale (Ch). The geological and morphological characteristics of the JFES landslide have been well documented (Huang et al., 2002; Shou and Wang, 2003; Wang et al., 2003a; Chang et al., 2005a,b). Therefore, only the geological investigations of the HTP landslide are described in detail herein.

\section{Surface and subsurface investigations of the Hungtsaiping landslide}

The area extent, depth, and mechanism of HTP landslide were identified from aerial photo interpretation, geological field investigation and drilling of boreholes. A geological map of the HTP area is shown in Fig. 4. The axis of the Syncline A was 


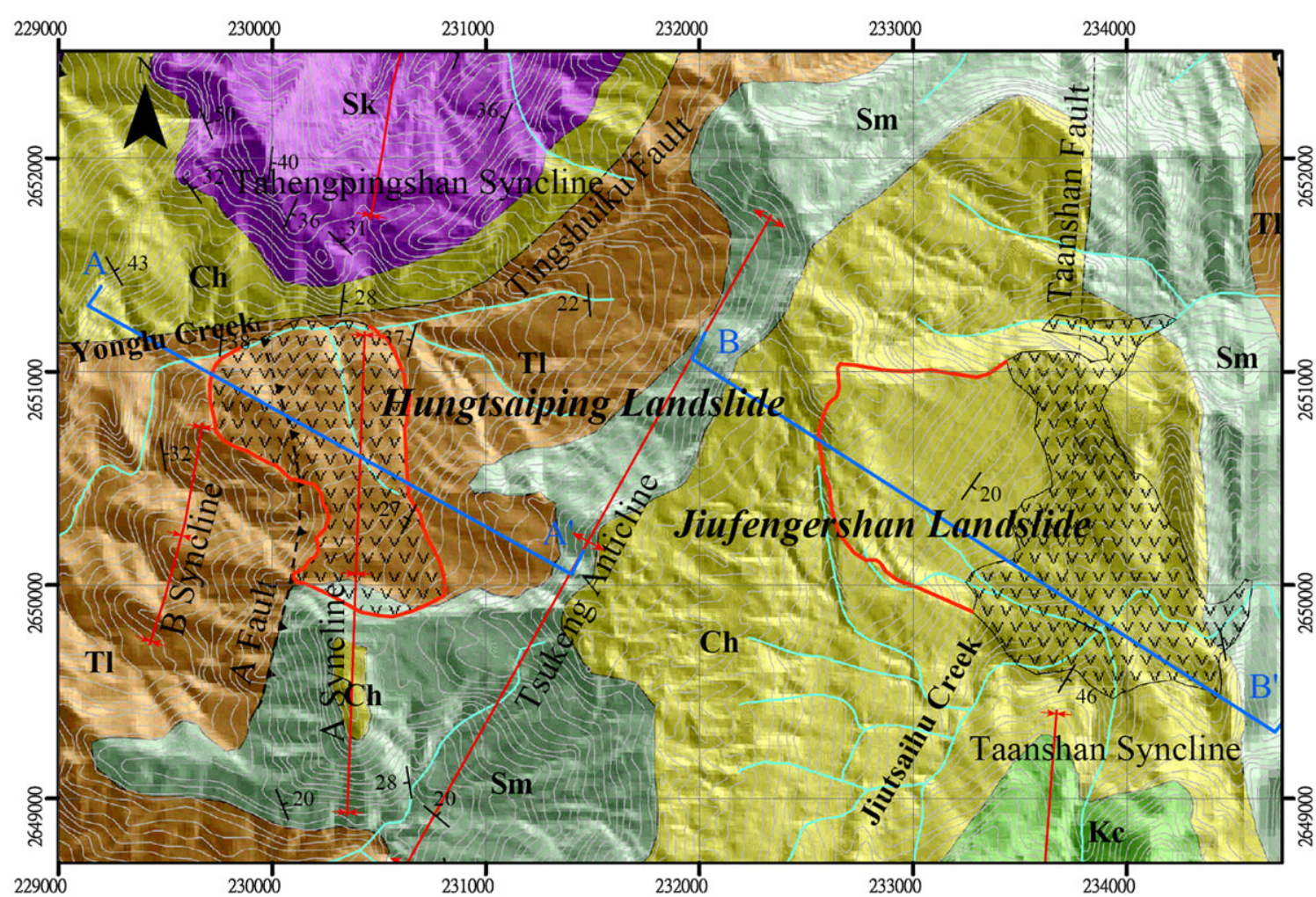

A

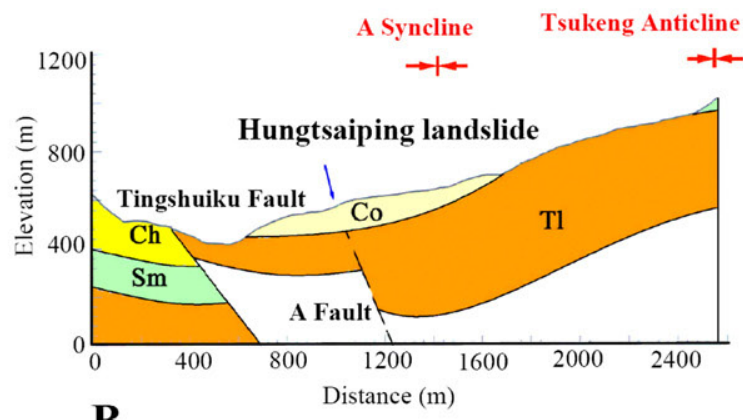

B

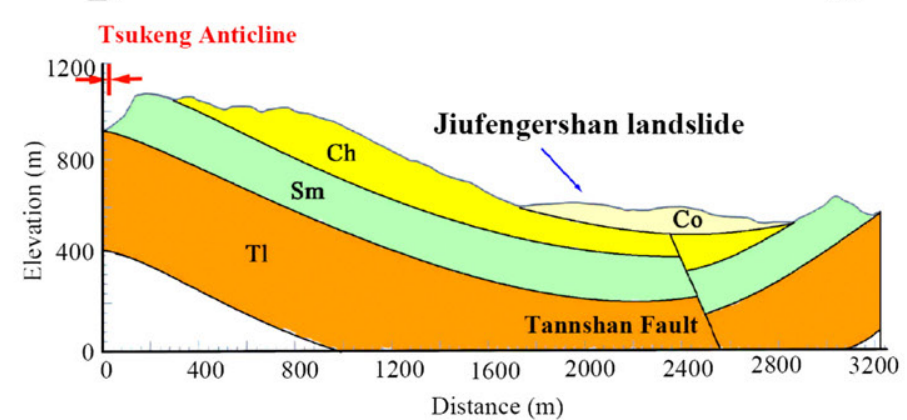

$\mathbf{A}^{\prime}$
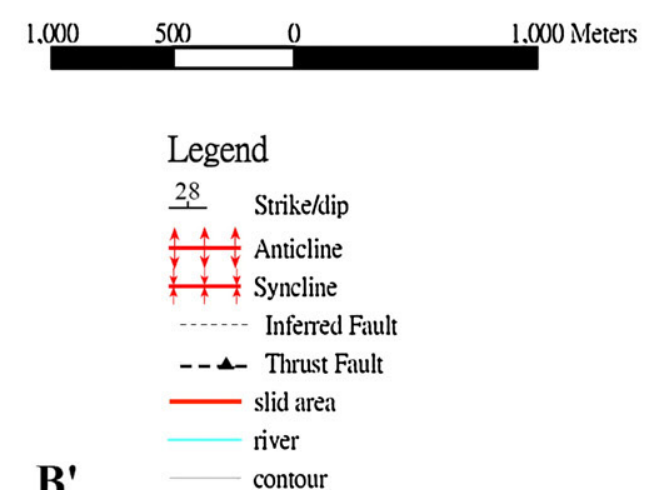

evv Slid materials trigged by Chi-Chi EQ

Formation

\begin{tabular}{|c|c|}
\hline Co & Colluvium \\
\hline $\mathrm{Kc}$ & Kueichulin Formation \\
\hline Sk & Shenkeng Sandstone \\
\hline $\mathrm{Ch}$ & Changhukeng \\
\hline $\mathrm{Sm}$ & Shihmen Formation \\
\hline $\mathrm{Tl}$ & Tanliaoti Shale \\
\hline
\end{tabular}

Fig. 3. Geological map of the HTP and JFES landslides (modified from Huang et al., 2000). Cross-sections A-A' and B-B' show the topography, geological structures and underlain strata.

constrained by the measured orientation of the bedding planes. $\mathrm{M}$ symmetry minor folds of thin-bedded siltstone and sandstone layers within a massive shale (Tanliaoti Shale) crop out on the river bank of Yonglu creek (Fig. 4), and these M folds should coincide with the hinge of a large fold structure (syncline A).
In Yonglu Creek, the outcrop of the Tingshuku fault was discovered. From the aerial photo, the scarp of the landslide can be easily recognized as the southern boundary. The maximum vertical displacement across the scarp is almost $20 \mathrm{~m}$. The eastern boundary of the HTP landslide follows Creek A. The 


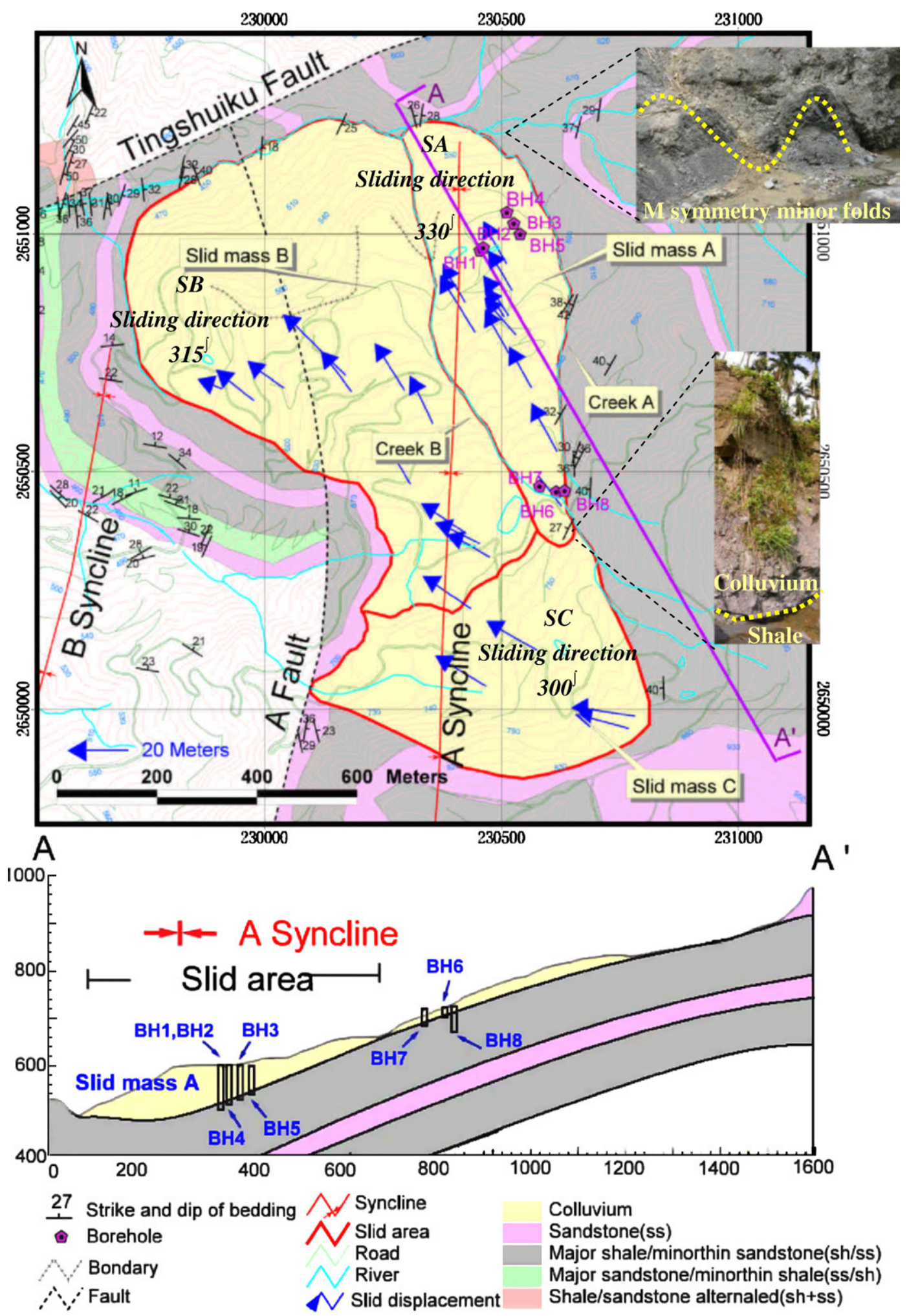

Fig. 4. Geological map of the HTP area according to the results of surface and subsurface investigation. The cross-section A- $\mathrm{A}^{\prime}$ is along the direction of mass movement between Creek A and Creek B $\left(330^{\circ}\right)$. The interface between the shale and the colluvium was mainly a bedding plane. M symmetry minor folds of thinbedded siltstone and sandstone layers within a massive shale crop out on the river bank of Yonglu creek.

western boundary of the HTP landslide is mainly along a ridge composed of massive sandstone. The sliding area is about 88.6 ha which is smaller than that identified by Lee et al. (2004).
According to the topographic characteristics and field investigation (Fig. 4), the HTP landslide area is underlain by thick colluvial deposits. Therefore, the failure mechanism may 

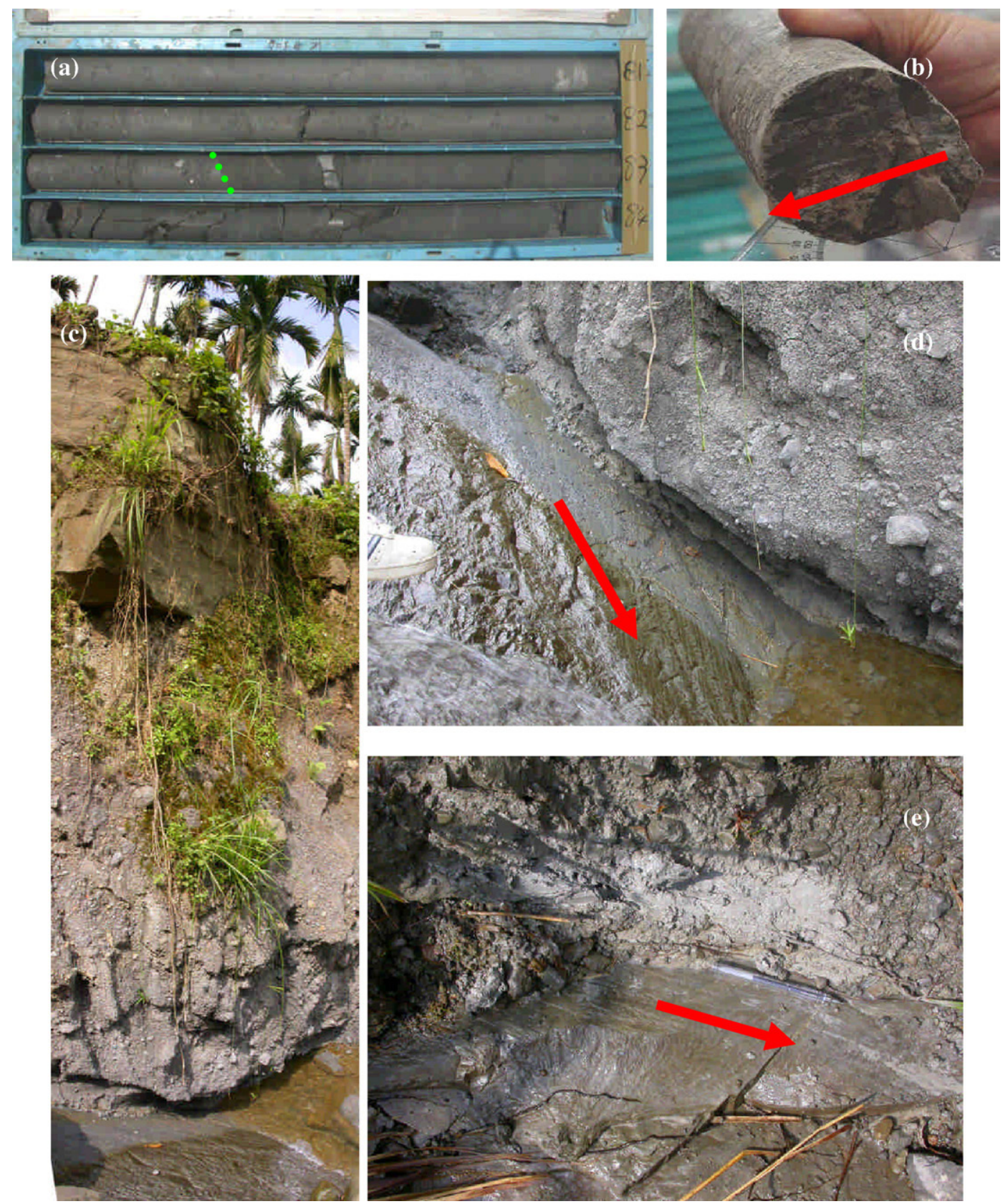

Fig. 5. Slickensides observed in the shale cores and in outcrops of the HTP landslide. (a) Shale core from 80-84 $\mathrm{m}$ of BH-1. The interface between the colluvium and the shale was marked with a dot line. (b) Striations on the slickensided plane at $82.3 \mathrm{~m}$ below the ground surface in borehole BH-1. The slickensided plane separates the colluvium and the shale. The measured plunge of striations on the slickensided plane was $21^{\circ}$. (c) Sliding surface with striations in outcrop in Creek A, $100 \mathrm{~m}$ upstream from BH-8. A colluvium layer of $8 \mathrm{~m}$ thick overlies the thick shale. The trend/plunge of striations observed on the slickensided plane in Creek A is $341^{\circ} / 15^{\circ}$. (d) Close view of the sliding surface. (e) The same sliding surface in outcrop $100 \mathrm{~m}$ further upstream.

not be considered as a dip slope rock slide, as indicated in the previous study (Lee et al., 2004; Wei and Lee, 2006). There are three distinct displaced masses (SA, SB, SC) composed of thick colluvial deposits. The directions of surface movement of SA, SB and SC (displacement vectors shown in Figs. 1 and 4) trend $330^{\circ}, 315^{\circ}$ and $300^{\circ}$, respectively. Eight boreholes were drilled in the landslide mass between Creek A and Creek B (SA). The borehole locations are shown in Fig. 4. Colluvial deposits overlying thick, fractured shale were observed in the cores (see
Fig. 5(a)). The thickness of colluvial deposits based on the borehole investigation is shown in Table 1. The colluvial deposits should originally come from the ridge southeast of the HTP landslide. It is believed that ancient landslides there include dip slope rock slides along the bedding plane of shale $\mathrm{(Tl})$ and a rock fall of massive sandstone $(\mathrm{Sm})$. The ridge (right side of $\mathrm{A}-\mathrm{A}^{\prime}$ cross-section) that is parallel to the Tsukeng anticline is inferred to be the scarp of an ancient dip slope slide. The displaced material accumulated in its current position and 
Table 1

Thickness of colluvium in displaced mass SA of the HTP landslide

\begin{tabular}{|c|c|c|c|c|c|c|c|c|}
\hline & BH-1 & BH-2 & BH-3 & BH-4 & BH-5 & BH-6 & BH-7 & BH-8 \\
\hline E.L. $(\mathrm{m})$ of borehole top & 591.0 & 591.0 & 590.0 & 588.0 & 590.0 & 712.0 & 709.0 & 713.0 \\
\hline E.L. (m) of interface (between shale and colluvial deposit) & 508.7 & 508.7 & 526.8 & 519.6 & 538.5 & 698.8 & 682.0 & 701.0 \\
\hline Thickness (m) of colluvial deposit & 82.3 & 82.3 & 63.2 & 68.4 & 51.5 & 13.2 & 27.0 & 12.0 \\
\hline
\end{tabular}

forms the thick colluvial deposits. The varied particle size of the colluvium may reflect the complex process of ancient landslides.

Slickensides observed in the shale cores (see Fig. 5(b)) suggested that the interface between the shale and the colluvium was a sliding surface. The measured plunge of striations observed on the slickensided plane was $21^{\circ}$. An slickensided plane (bedding plane of shale; $\mathrm{N} 24^{\circ} \mathrm{E} / 27^{\circ} \mathrm{NW}$ ) was also observed in outcrop in Creek A (see Fig. 5(c)-(e)). Thus, the observed striations in rock core and in outcrop may well be a mark induced by the Chi-Chi earthquake triggered landslide. The trend of the striations observed on the slickenside plane is $341^{\circ}$ and the measured plunge $15^{\circ}$. The trend of striation measured from the slickenside plane is almost identical with that of surface movement $\left(330^{\circ}\right)$ between Creek A and Creek B (SA) after the Chi-Chi earthquake. Using the three point method, the orientation of the interface between the colluvium and shale observed in BH-1(EL.508.7 m), BH-4(EL519.6 m), and BH-5(EL.538.5 m) was determined as $\mathrm{N} 19^{\circ} \mathrm{E} / 23^{\circ} \mathrm{NW}$, which is almost parallel to the measured bedding plane $\left(\mathrm{N} 24^{\circ} \mathrm{E} /\right.$ $27^{\circ} \mathrm{NW}$ ) in Creek A. Consequently, during the Chi-Chi earthquake the displaced mass SA between Creek $\mathrm{A}$ and Creek B probably slid mainly along the interface between colluvium and shale which happened also to be a bedding plane of the underlying shale. It is interesting to note that the sliding direction is not coincident with the dip direction of the sliding plane (bedding plane of shale). The apparent dips along the direction of surface movement $\left(330^{\circ}\right)$ of the displaced mass SA are $22^{\circ}$ and $18^{\circ}$ on the sliding plane as measured in Creek A $\left(\mathrm{N} 24^{\circ} \mathrm{E} / 27^{\circ} \mathrm{NW}\right)$ and as calculated based on three point method
$\left(\mathrm{N} 19^{\circ} \mathrm{E} / 23^{\circ} \mathrm{NW}\right)$, respectively. Fig. 4 shows the cross-section along the direction of surface movement $\left(330^{\circ}\right)$ of displaced mass SA. Most of the sliding surface is planar. The representative apparent dip is $21^{\circ}$ along the direction of surface movement $\left(330^{\circ}\right)$ of SA. Near the toe of the slope, the sliding surface (mainly along the bedding plane) is inferred to become curved as the sliding surface passes through the axis of A Syncline (Fig. 4). To simplify the analysis, only the planar sliding surface is considered. The mechanism of displaced masses SB and SC is less clear due to a lack of information at the present. Therefore, the following discussion focuses on displaced mass SA where the sliding surface was clearly identified. The representative trend/plunge of the sliding direction $330^{\circ} / 21^{\circ}$ were used to calculate the Newmark displacement of the HTP landslide instead of the locally measured trend and plunge of the striations on slickenside plane. Accordingly, the plunge of the sliding vector is identical with that of JFES landslide although the sliding directions are different.

\section{Seismic anisotropy of Chi-Chi earthquake and induced direction-dependent Newmark displacement}

To explore the directional effects of seismic anisotropy on the earthquake-induced landslides, dimensionless indices that include direction-dependent (1) horizontal pseudostatic coefficients and (2) earthquake energy ratios were proposed and calculated using the strong-motion records of the Chi-Chi earthquake. In addition, a sliding-block method (Huang et al., 2001) was used to compute the permanent sliding-block

Table 2

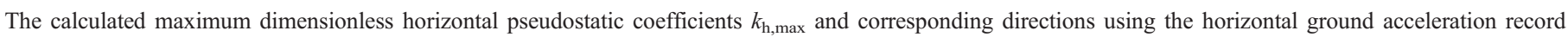
during the Chi-Chi earthquake from 12 selected strong-motion stations

\begin{tabular}{|c|c|c|c|c|c|c|}
\hline Structural zone ${ }^{\mathrm{a}}$ & Strong-motion station & Distance to epicenter $(\mathrm{km})$ & Distance to the JFES/HTP landslides (km) & Elevation $(\mathrm{m})$ & Site class ${ }^{\mathrm{b}}$ & $k_{\mathrm{h}, \max } /$ direction \\
\hline \multirow[t]{5}{*}{ Zone I } & TCU065 & 26.7 & $19 / 17$ & 59 & $\mathrm{D}$ & $0.85 / 107^{\circ}(\mathrm{ESE})$ \\
\hline & TCU067 & 28.7 & $19 / 18$ & 95 & $\mathrm{D}$ & $0.58 / 303^{\circ}(\mathrm{NW})$ \\
\hline & TCU075 & 20.6 & $17 / 14$ & 102 & $\mathrm{D}$ & $0.33 / 265^{\circ}(\mathrm{W})$ \\
\hline & TCU076 & 16.0 & $18 / 15$ & 99 & $\mathrm{D}$ & $0.42 / 7^{\circ}(\mathrm{N})$ \\
\hline & TCU129 & 14.0 & $18 / 16$ & 108 & $\mathrm{D}$ & $1.03 / 280^{\circ}(\mathrm{WNW})$ \\
\hline \multirow[t]{2}{*}{ Zone II } & TCU071 & 15.3 & $6 / 4$ & 237 & $\mathrm{C}$ & $0.77 / 216^{\circ}(\mathrm{SW})$ \\
\hline & TCU072 & 21.3 & $9 / 10$ & 292 & $\mathrm{D}$ & $0.49 / 92^{\circ}(\mathrm{ESE})$ \\
\hline \multirow[t]{3}{*}{ Zone III } & TCU078 & 4.9 & $16 / 17$ & 280 & $\mathrm{D}$ & $0.47 / 291^{\circ}(\mathrm{WNW})$ \\
\hline & TCU089 & 7.0 & $6 / 7$ & 702 & $\mathrm{C}$ & $0.36 / 248^{\circ}(\mathrm{W})$ \\
\hline & TCU074 & 19.1 & $12 / 15$ & 441 & $\mathrm{D}$ & $0.62 / 104^{\circ}(\mathrm{ESE})$ \\
\hline \multirow[t]{2}{*}{ Zone IV } & TCU079 & 7.8 & $14 / 16$ & 693 & $\mathrm{D}$ & $0.74 / 266^{\circ}(\mathrm{W})$ \\
\hline & TCU084 & 9.0 & $10 / 12$ & 1008 & $?$ & $1.16 / 271^{\circ}(\mathrm{WNW})$ \\
\hline
\end{tabular}

a The structural zones are shown in Fig. 2. The JFES and HTP landslides are located in Zone III.

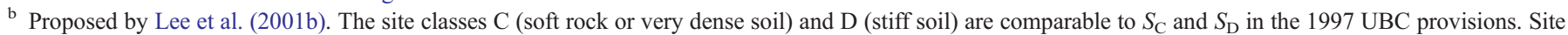
class?: questionable station. 
displacements (Newmark displacement) induced by Chi-Chi earthquake in different directions. The Chelungpu fault, epicenter of Chi-Chi earthquake and the 12 strong-motion stations near the two studied landslides are shown in Fig. 2. The recorded strong-motions of the main-shock of Chi-Chi earthquake filtered by baseline corrections and band-pass

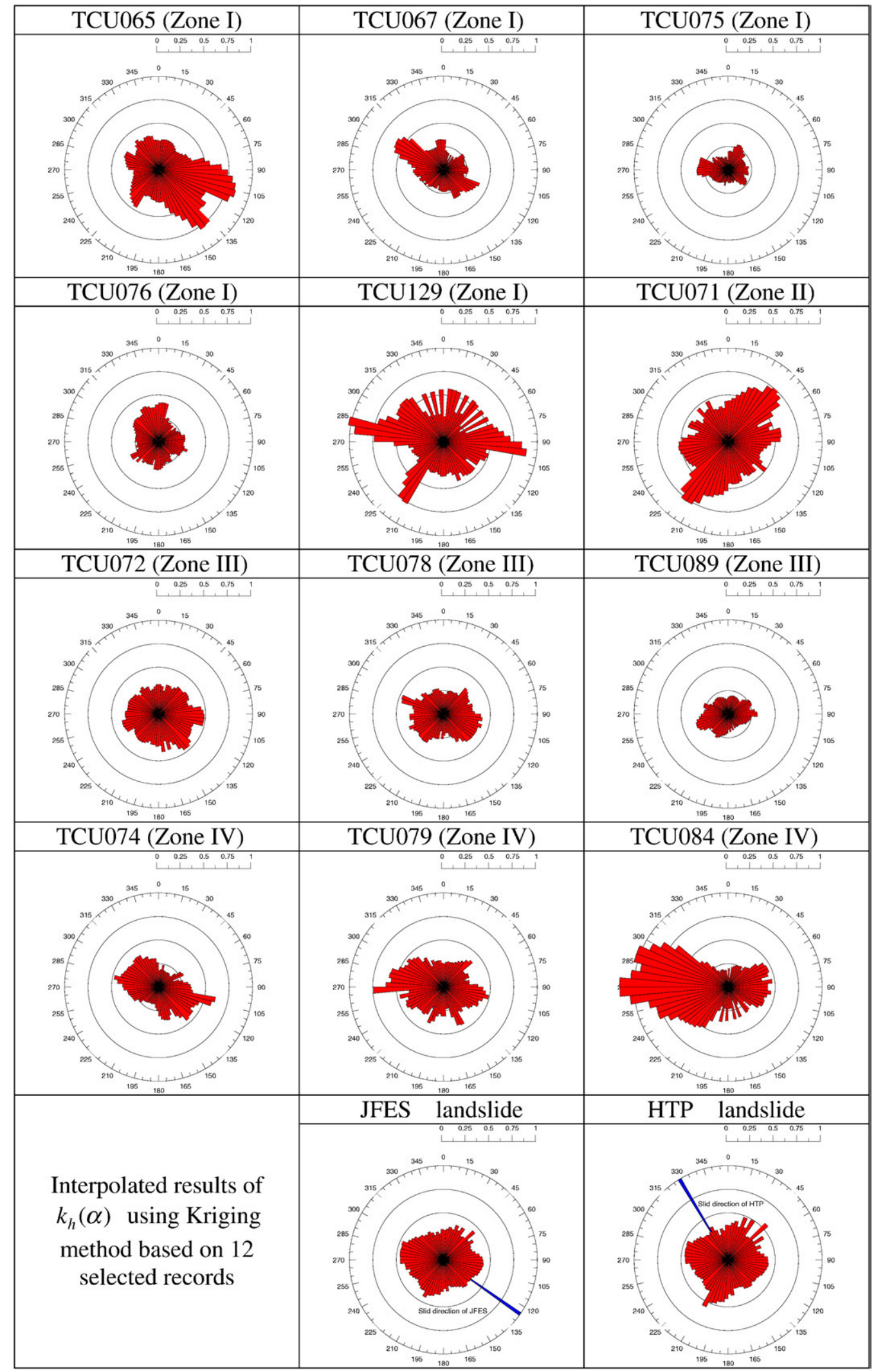

Fig. 6. The direction-dependent dimensionless horizontal pseudostatic coefficients $k_{\mathrm{h}}(\alpha)$ of the 12 selected strong-motion records during the Chi-Chi earthquake. 
filtering (Lee et al., 1999, 2001a) were utilized in the analysis. To take the geological structure into account, the strongmotion stations were categorized into four structural zones (I-IV) as shown in Fig. 2. The distances from these strong-motion stations to the epicenter and to the studied landslides are summarized in Table 2.

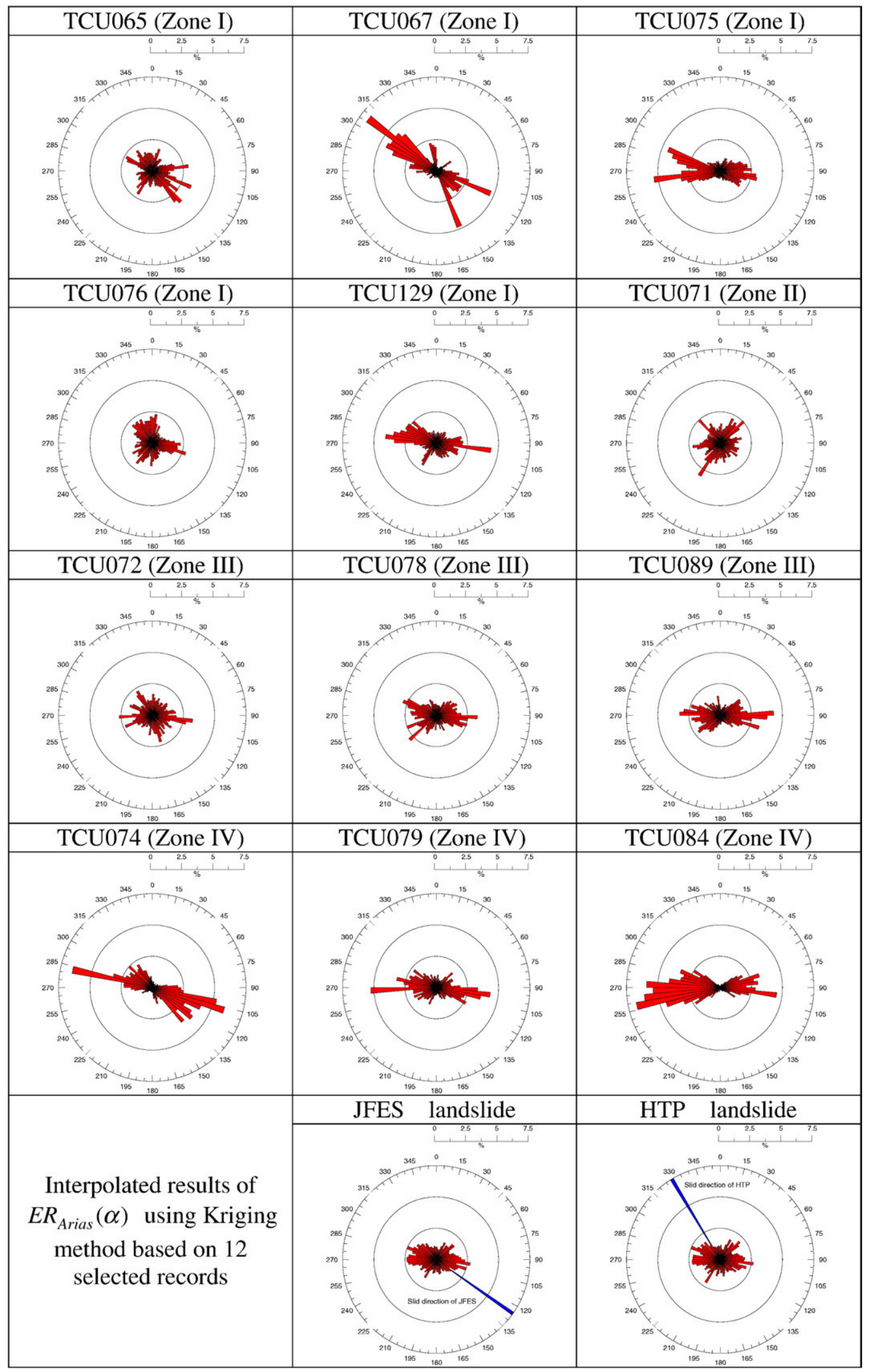

Fig. 7. The direction-dependent dimensionless earthquake energy ratios selected strong-motion records during the Chi-Chi earthquake. 


\subsection{Direction-dependent dimensionless horizontal pseudostatic coefficients}

Pseudostatic analysis represents the effects of earthquake shaking by pseudostatic accelerations that produce inertial forces which act through the centroid of the sliding mass (Kramer, 1996). The horizontal force sustained by the sliding mass is proportional to the dimensionless horizontal pseudostatic coefficient $k_{\mathrm{h}}$. The authors calculated the horizontal acceleration vectors $a_{\mathrm{h}}(\alpha, t)=\sqrt{a_{\mathrm{EW}}^{2}+a_{\mathrm{NS}}^{2}}$ at each time interval $(0.005 \mathrm{~s})$, where $a_{\mathrm{EW}}$ and $a_{\mathrm{NS}}$ are the $\mathrm{E}-\mathrm{W}$ and $\mathrm{N}-\mathrm{S}$ components of horizontal accelerations and $\alpha=\tan ^{-1}\left(a_{\mathrm{EW}} / a_{\mathrm{NS}}\right)$ is the phase angle of these $\mathrm{E}-\mathrm{W}$ and $\mathrm{N}-\mathrm{S}$ components of horizontal accelerations. The dimensionless horizontal pseudostatic coefficient $k_{\mathrm{h}}(\alpha, t)=a_{\mathrm{h}}(\alpha, t) / g$, in which $g$ represents the gravity acceleration.

The peak value of dimensionless horizontal pseudostatic coefficients in direction is expressed as $k_{\mathrm{h}}(\alpha)$. The $k_{\mathrm{h}}(\alpha)$ of the 12 strong-motion records in different directions were calculated and expressed as rose diagrams in Fig. 6. The corresponding maximum dimensionless horizontal pseudostatic coefficients $k_{\mathrm{h}}$, $\max$ and their directions for the 12 selected records are summarized in Table 2. According to Table 2, all $k_{\mathrm{h} \text {,max }}$ of Zone III and Zone IV are $\operatorname{ESE}\left(101.25^{\circ}-123.75^{\circ}\right), \mathrm{W}\left(258.75^{\circ}-281.25^{\circ}\right)$, or $\mathrm{WNW}$ $\left(281.25^{\circ}-303.75^{\circ}\right)$ trending. In Zone I and Zone II, the trends of $k_{\mathrm{h} \text {,max }}$ are more scattered than the ones derived from the other two Zones. In general, the shaking is predominantly in the E-W and ESE-WNW trending (see Fig. 6). The only exception is the record of TCU071 (Zone II) where the shaking is predominantly $\mathrm{NE}-\mathrm{SW}$ trending.

It is notable that the recorded PGA from station TCU129 during Chi-Chi earthquake was above $1 \mathrm{~g}$. This high PGA value may be related to the use of a concrete platform underneath the station (Wen et al., 2001). Another case of PGA in excess of $1 \mathrm{~g}$ during Chi-Chi earthquake was recorded at TCU084. TCU084 is located on a very steep mountain summit, and so is a typical ridge top case (Shin, 2000) where the topographic effects may be significant. To clarify the site conditions of selected strongmotion stations, the site classifications proposed by Lee et al. (2001b) of the selected stations are shown in Table 2.

\subsection{Direction-dependent dimensionless earthquake energy ratio}

Arias intensity $I_{a}=\frac{2 \pi}{g} \int a_{\mathrm{h}}(t)^{2} d t$ (Arias, 1970), which reflects the characteristics of amplitude, frequency and duration of ground motion (Kramer, 1996), is a suitable descriptor of strong ground motion. The Arias intensity has been used to predict earthquake-induced landslides (Jibson, 1993). To evaluate the seismic anisotropy on the earthquake-induced landslides, the authors proposed a direction-dependent dimensionless earthquake energy ratio as follows:

$\operatorname{ER}_{\text {Arias }}(\alpha)=\frac{\sum_{t=0}^{T_{\mathrm{d}}} a_{\mathrm{h}}^{2}(\alpha, t) \cdot \Delta t}{\sum_{\alpha=0}^{2 \pi} \sum_{t=0}^{T_{\mathrm{d}}} a_{\mathrm{h}}^{2}(\alpha, t) \Delta t}$

in which $T_{\mathrm{d}}$ is the duration of earthquake and $\sum_{\alpha=0}^{2 \pi} \operatorname{ER}_{\text {Arias }}(\alpha)=1$. Thus, the dimensionless earthquake energy ratio $\operatorname{ER}_{\text {Arias }}(\alpha)=1$ represents the percentage of Arias intensity in a certain direction $\alpha$. The $\operatorname{ER}_{\text {Arias }}(\alpha)$ in five degree increments were accumulated and expressed as rose diagrams in Fig. 7. Fig. 7 shows that the $\operatorname{ER}_{\text {Arias }}(\alpha)$ is highly direction-dependent. The $\operatorname{ER}_{\text {Arias }}(\alpha)$ of the 12 selected strong-motion records in sixteen directions are shown in Table 3. According to Table 3,39.4\% of the Arias intensity concentrates in E-W and ESE-WNW trends for the 12 selected strong-motion stations. The concentrated trending of $\mathrm{ER}_{\text {Arias }}(\alpha)$ is

Table 3

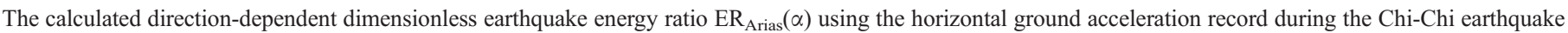
from 12 selected strong-motion stations

\begin{tabular}{|c|c|c|c|c|c|c|c|c|c|c|c|c|c|c|c|c|c|}
\hline \multirow{2}{*}{$\begin{array}{l}\text { Structural } \\
\text { zone }^{\mathrm{a}}\end{array}$} & \multirow{2}{*}{$\begin{array}{l}\text { Strong-motion } \\
\text { stations (zone) }\end{array}$} & \multicolumn{16}{|c|}{ Direction-dependent dimension less earthquake energy ratio (\%) } \\
\hline & & $\mathrm{N}$ & NNE & $\mathrm{NE}$ & ENE & $\mathrm{E}$ & ESE & SE & SSE & $\mathrm{S}$ & SSW & SW & WSW & $\mathrm{W}$ & WNW & NW & NNW \\
\hline \multirow{5}{*}{ Zone I } & TCU065 (I) & 6.0 & 5.6 & 3.2 & 5.2 & 8.5 & 8.7 & 11.5 & 5.8 & 4.5 & 5.0 & 6.7 & 4.7 & 4.1 & 7.2 & 7.1 & 6.2 \\
\hline & TCU067 (I) & 6.2 & 1.0 & 1.9 & 3.3 & 5.1 & 11.8 & 9.4 & 9.6 & 2.1 & 2.0 & 2.5 & 2.5 & 6.4 & 13.5 & 18.9 & 3.8 \\
\hline & TCU075 (I) & 2.6 & 3.6 & 4.6 & 7.5 & 10.9 & 9.2 & 6.2 & 3.2 & 2.4 & 2.6 & 3.1 & 9.1 & 15.0 & 12.8 & 4.1 & 3.1 \\
\hline & TCU076 (I) & 9.3 & 4.8 & 3.6 & 4.0 & 8.0 & 8.8 & 4.3 & 5.1 & 6.2 & 5.6 & 7.4 & 5.3 & 5.2 & 5.5 & 8.8 & 8.1 \\
\hline & TCU129 (I) & 3.4 & 3.5 & 4.4 & 4.9 & 11.6 & 7.3 & 5.3 & 5.1 & 4.1 & 4.2 & 5.8 & 4.3 & 12.1 & 12.2 & 8.3 & 3.5 \\
\hline \multicolumn{2}{|c|}{ Average of Zone I } & 5.9 & 4.3 & 4.5 & 5.0 & 7.7 & 8.9 & 7.5 & 5.7 & 4.2 & 4.4 & 5.5 & 5.3 & 7.8 & 8.8 & 9.1 & 5.4 \\
\hline \multirow[t]{2}{*}{ Zone II } & TCU071 (II) & 5.6 & 6.7 & 9.0 & 5.0 & 5.9 & 6.0 & 5.9 & 5.0 & 5.9 & 7.0 & 8.0 & 4.8 & 8.0 & 4.8 & 6.5 & 5.9 \\
\hline & TCU072 (III) & 5.8 & 5.2 & 5.6 & 5.3 & 10.0 & 7.3 & 5.7 & 7.4 & 6.0 & 3.6 & 5.0 & 7.1 & 7.3 & 6.2 & 5.9 & 6.6 \\
\hline \multirow[t]{2}{*}{ Zone III } & TCU078 (III) & 3.8 & 3.6 & 6.2 & 7.3 & 10.4 & 9.0 & 4.1 & 4.2 & 3.7 & 5.3 & 7.7 & 7.0 & 8.2 & 9.8 & 5.5 & 4.2 \\
\hline & TCU089 (III) & 3.7 & 3.0 & 5.5 & 8.0 & 13.7 & 8.9 & 4.7 & 2.1 & 2.8 & 4.8 & 8.1 & 6.9 & 11.4 & 7.6 & 5.2 & 3.6 \\
\hline \multicolumn{2}{|c|}{ Average of Zone III } & 4.3 & 3.9 & 5.8 & 6.9 & 11.4 & 8.4 & 4.8 & 4.6 & 4.2 & 4.6 & 6.9 & 7.0 & 9.0 & 7.9 & 5.5 & 4.8 \\
\hline \multirow{3}{*}{ Zone IV } & TCU074 (IV) & 2.8 & 1.4 & 1.3 & 1.9 & 8.7 & 19.3 & 13.8 & 4.2 & 2.2 & 1.3 & 2.0 & 3.0 & 9.0 & 14.1 & 9.1 & 5.9 \\
\hline & TCU079 (IV) & 3.8 & 2.6 & 5.0 & 5.5 & 11.8 & 11.0 & 4.9 & 3.0 & 2.6 & 4.3 & 5.6 & 6.5 & 13.5 & 9.9 & 6.7 & 3.3 \\
\hline & TCU084(IV) & 0.3 & 0.9 & 3.2 & 10.1 & 13.9 & 5.7 & 2.4 & 0.9 & 0.7 & 1.1 & 4.3 & 14.4 & 25.8 & 12.2 & 3.4 & 0.7 \\
\hline \multicolumn{2}{|c|}{ Average of Zone IV } & 2.3 & 1.6 & 3.2 & 5.8 & 11.5 & 12.0 & 7.0 & 2.7 & 1.8 & 2.2 & 4.0 & 8.0 & 16.1 & 12.1 & 6.4 & 3.3 \\
\hline \multicolumn{2}{|c|}{ Average of Zones I, II, III, IV } & 4.4 & 3.5 & 4.5 & 5.7 & 9.9 & 9.4 & 6.5 & 4.6 & 3.6 & 3.9 & 5.5 & 6.3 & 10.5 & 9.6 & 7.5 & 4.6 \\
\hline
\end{tabular}

Maximum $\mathrm{ER}_{\text {Arias }}(\alpha)$ is shown in bold. The top four $\mathrm{ER}_{\text {Arias }}(\alpha)$ for a given strong-motion station are shaded.

a The structural zones are shown in Fig. 2. The JFES and HTP landslides are located in Zone III. 


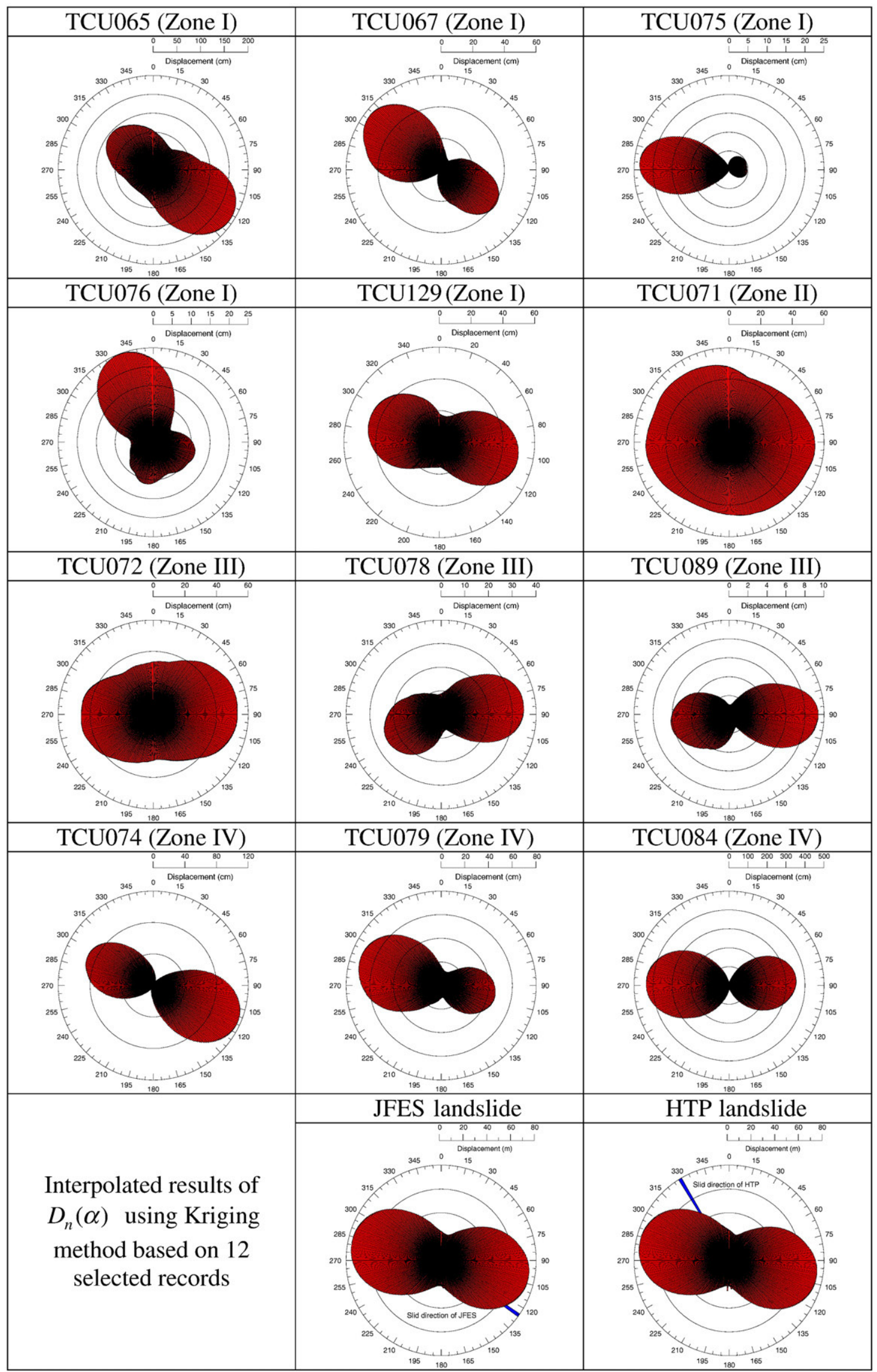

Fig. 8. The direction-dependent Newmark displacements $D_{\mathrm{n}}(\alpha)$ of the sliding block on planes with $21^{\circ}$ dip angle. The friction angle of the sliding plane is assumed as $28^{\circ}$. The strong-motion records of 12 selected stations during the Chi-Chi earthquake were used. 
identical to the predominant trending of $k_{\mathrm{h}}(\alpha)$, although directional dependency of $\operatorname{ER}_{\text {Arias }}(\alpha)$ (Fig. 7) is more obvious than that of $k_{\mathrm{h}}(\alpha)$ (Fig. 6). Generally speaking, the distributions of $\operatorname{ER}_{\text {Arias }}(\alpha)$ are similar for different structural zones. The only exception is again the strong-motion record of TCU071.

\subsection{Direction-dependent Newmark displacement}

Newmark (1965) proposed a displacement-based analysis method to calculate the permanent displacement of a translation block under horizontal ground acceleration $a(t)$. The equation of motion of a rigid block on a cohesionless sliding plane with an incline angle $\theta$ is (Crespellani et al., 1998):

$\ddot{x}(t)=\left[a(t)-A_{\mathrm{c}}\right] \frac{\cos (\phi-\theta)}{\cos \phi}$

where $\ddot{x}(t)$ is the relative acceleration between the block and the sliding plane and $\phi$ is the friction angle between the sliding mass and the sliding surface. $A_{\mathrm{c}}$ is the critical acceleration which can be expressed as:

$A_{\mathrm{c}}=\frac{\tan \phi-\tan \theta}{1+\tan \phi \tan \theta} \cdot g=\tan (\phi-\theta) \cdot g$

Integration of $\ddot{x}(t)$ derives the relative velocity $v(t)$ between the block and sliding plane. The permanent displacement $d(t)$ of the block is calculated by integration with time of the relative velocity. Huang et al. (2001) suggested that the vertical component of the acceleration records is important for calculating the permanent displacement of a sliding block. The Newmark's (1965) sliding-block method was modified according to the suggestion by Huang et al. (2001) to analyze the initiation of the JFES landslide and determine Newmark displacements of sliding blocks along inclined planes with different orientations. In this modified sliding-block method, the vertical, NS, and EW components of the acceleration were converted to those in directions normal and tangential to the sliding surface along the dip and strike. Since the contribution of cohesion on the sliding resistance is minimal for a deep- seated landslide (Huang et al., 2001), Eqs. (2) and (3) are used for the following calculations.

Based on the 12 selected strong-motion records, the Newmark displacements at the end of shaking, $D_{\mathrm{n}}(\alpha)$ of the sliding blocks on a plane with $21^{\circ}$ dip were calculated in different sliding directions (every $1^{\circ}$ ) using the modified slidingblock method. The friction angle of the sliding block was assumed to be $28^{\circ}$ (the residual friction angle between sandstone and shale after one month saturation was $27.3^{\circ}$ according to Shou and Wang (2003)) and to remain constant during block sliding. The $D_{\mathrm{n}}(\alpha)$ of the sliding block demonstrated in Fig. 8 are highly direction-dependent. Basically, the direction-dependent $D_{\mathrm{n}}(\alpha)$ is peanut shaped with the exception of TCU071. The maximum $D_{\mathrm{n}}$ of the sliding block tends to concentrate in $\mathrm{E} / \mathrm{W}$ and ESE/WNW directions which reflects the effect of seismic anisotropy (Figs. 6 and 7). The directional dependency of $D_{\mathrm{n}}(\alpha)$ is stronger than that of $k_{\mathrm{h}}(\alpha)$ and $\mathrm{ER}_{\text {Arias }}(\alpha)$. This is because that $D_{\mathrm{n}}$ of the sliding block is not proportional to the acceleration or earthquake energy. Significantly higher $D_{\mathrm{n}}$ of sliding block would be induced when the acceleration exceeded $A_{\mathrm{c}}$. The results shown in Figs. 6-8 clearly demonstrated the seismic anisotropy of Chi-Chi earthquake and its influence on $D_{\mathrm{n}}(\alpha)$ of a block sliding in different directions. It is worthy to mention that the direction of calculated maximum $D_{\mathrm{n}}(\alpha)$ based on the strong-motion records of different structural zones can be different. The directions of calculated maximum $D_{\mathrm{n}}$ from Zone III (TCU072, TCU074, TCU089) are E trending, while those of TCU079 and TCU084 (Zone IV) are WNW and W trending, respectively. The directions of maximum $D_{\mathrm{n}}$ from Zone I are more scatter (ESE, NW, W, NNW, and ES).

\subsection{Effects of seismic anisotropy on $D_{n}$ in sliding direction}

To study the effect of seismic anisotropy on the two gigantic landslides in different sliding directions, the inferred directiondependent $k_{\mathrm{h}}(\alpha), \mathrm{ER}_{\text {Arias }}(\alpha)$ and $D_{\mathrm{n}}(\alpha)$ at the JFES and HTP landslide areas based on the 12 selected records were interpolated using the Kriging method (Isaaks and Srivastava, 1989). The

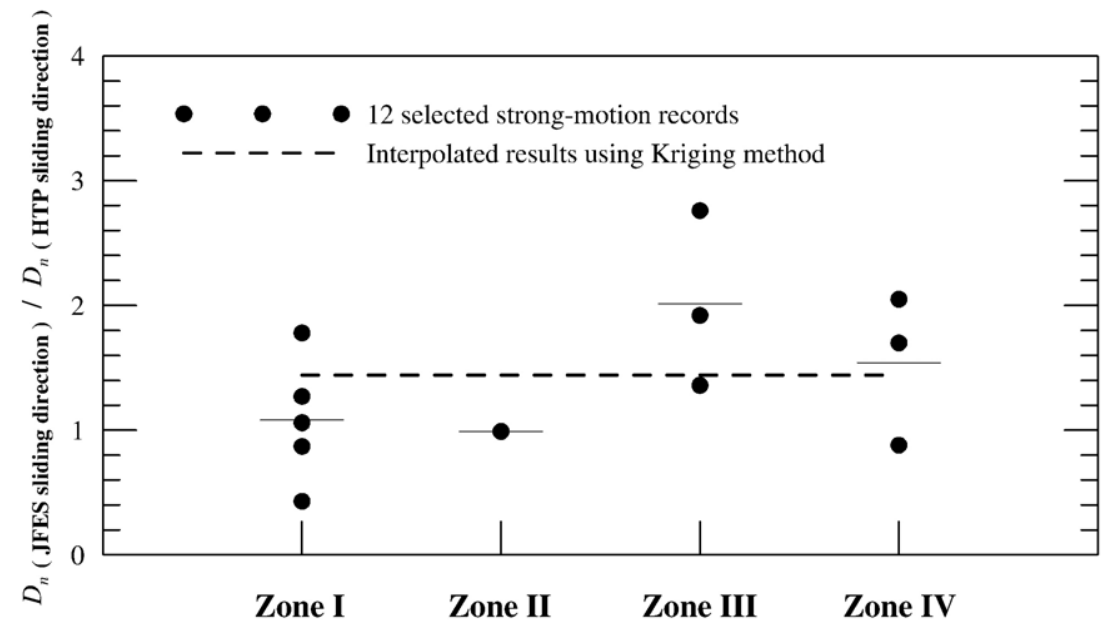

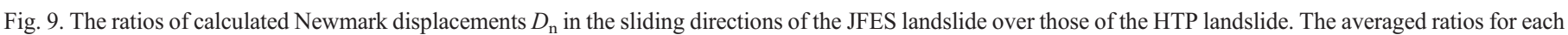
structure zone are indicated by short lines. The ratios interpolated using Kriging method from 12 strong-motion records are indicated by the dash line. 
interpolated results are shown in Figs. 6-8. Since the two subject landslides are as close as $2 \mathrm{~km}$ from each other, the distribution of the Kriging interpolated $k_{\mathrm{h}}(\alpha), \mathrm{ER}_{\text {Arias }}(\alpha)$ and $D_{\mathrm{n}}(\alpha)$ of the two landslides should be similar as in the case of Figs. 6-8.

The interpolated $k_{\mathrm{h}}(\alpha)$ (Fig. 6) in the sliding direction of the JFES landslide (126 $6^{\circ}$ SE trending) and HTP landslide (330 ; NNW trending) are 0.36 and 0.35 , respectively. There is no apparent difference in $k_{\mathrm{h}}(\alpha)$ in the sliding direction between JFES and HTP landslides. The $\operatorname{ER}_{\text {Arias }}(\alpha)$ from Kriging interpolation (Fig. 7) in the direction of the JFES landslide (SE trending) are identical to that of the HTP landslide (NNW trending). In spite of the minor discrepancies in $k_{\mathrm{h}}(\alpha)$ and $\mathrm{ER}_{\text {Arias }}(\alpha)$ in $126^{\circ} / 330^{\circ}$ trending of the JFES/HTP landslides, the differences in $D_{\mathrm{n}}(\alpha)$ along the sliding directions with plunge of $21^{\circ}$ are obvious. The permanent displacement of a sliding block represents an accumulated effect of accelerations in all directions. Thus, $D_{\mathrm{n}}$ in a given direction is not only governed by the acceleration in that direction. The interpolated $D_{\mathrm{n}}$ in the sliding direction of the JFES landslide $\left(126^{\circ}\right.$; SE trending) and HTP landslide $\left(330^{\circ}\right.$; NNW trending) are $65.0 \mathrm{~cm}$ and $45.0 \mathrm{~cm}$, respectively. That is, the impact of Chi-Chi earthquake is stronger (44\%) in the sliding direction of JFES landslide than
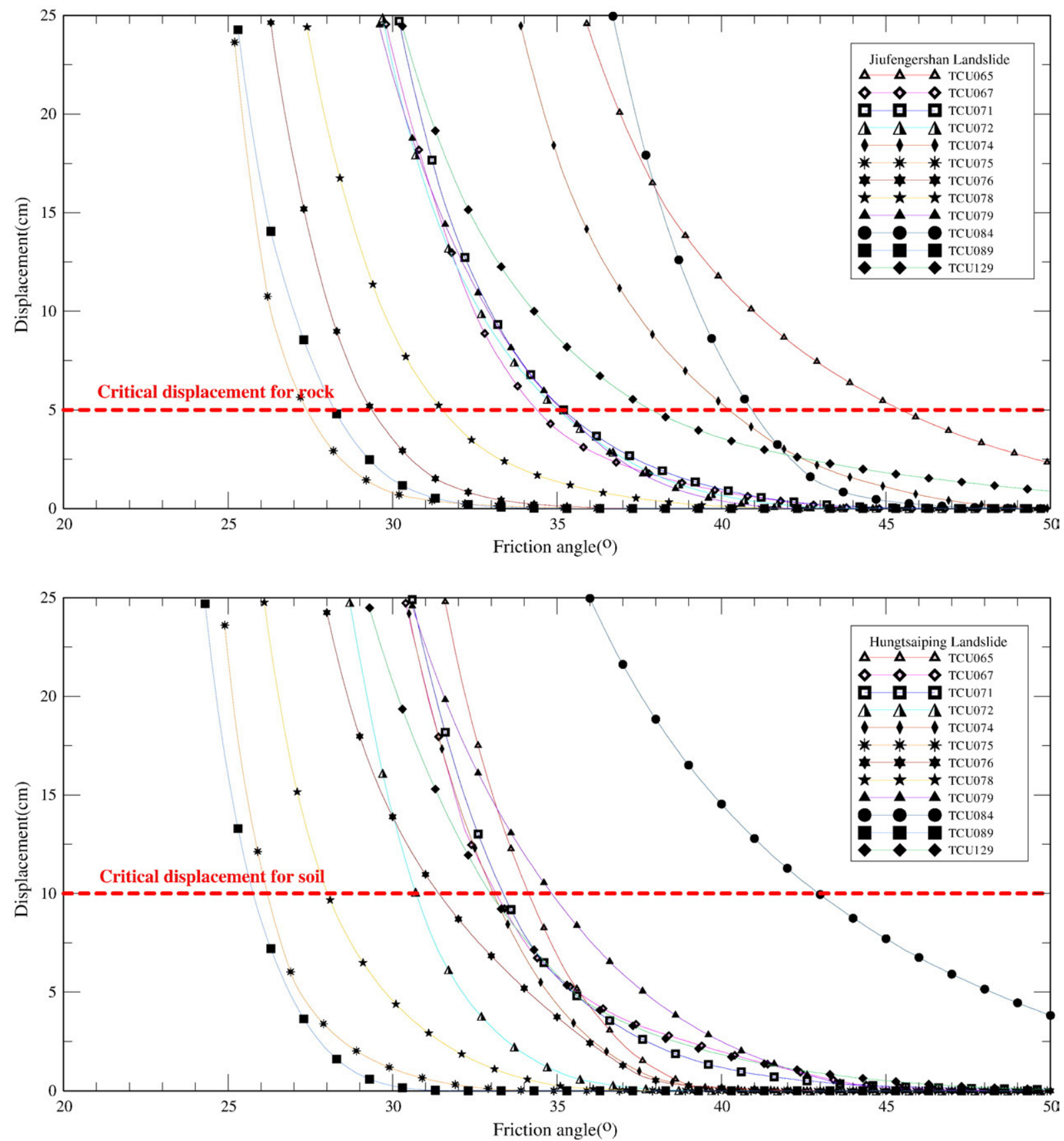

Fig. 10. The calculated Newmark displacements with different assumed friction angles (velocity-independent) in directions of the JFES landslide $\left(126^{\circ} / 21^{\circ}\right.$ ) and the HTP $\left(330^{\circ} / 21^{\circ}\right)$ landslide using modified sliding-block method. The strong-motion records of 12 selected stations during the Chi-Chi earthquake were used. Critical Newmark displacement $D_{\mathrm{n}, \mathrm{c}}$ for the JFES landslide (rock slope) and the HTP landslide (soil slope) were assumed as $5 \mathrm{~cm}$ and $10 \mathrm{~cm}$, respectively. 
that of HTP landslide. While seismic anisotropy can explain the differences in displacements between the two landslides, it is not sufficient however, to explain the substantially differences in the level of displacements. Such deficiency can be properly accounted for by the velocity-dependent friction law as will be introduced later.

Fig. 9 shows the ratios of $D_{\mathrm{n}}$ in $126^{\circ}$ trending (sliding direction of JFES landslide) over that in $330^{\circ}$ trending (sliding direction of HTP landslide) for each of the four geological zones. These ratios were determined using the strong-motion records from the Chi-Chi earthquake at the 12 selected stations. The averaged ratios for each structure zone are indicated by short lines. The interpolated ratio using Kriging method according 12 strong-motion records is 1.44 as indicated by a dash line in Fig. 9. In spite of some scattering, Fig. 9 shows that the averaged $D_{\mathrm{n}}$ ratios in Zone III and Zone IV are consistently larger than those in Zone I and Zone II. Among the 4 geological zones, the averaged ratio of $D_{\mathrm{n}}$ between the two landslides in their respective sliding directions is the largest in Zone III with a value of 2.01. Therefore, the selection of representative strongmotion records for evaluating the earthquake-induced landslides should not overlook the effects of geological structures.

\section{Friction angles of sliding surfaces of the two gigantic landslides}

\subsection{Critical Newmark displacement and friction angle of the sliding planes}

Fig. 10 shows the correlation between $D_{\mathrm{n}}$ and friction angle on the sliding plane for the case of JFES and the HTP landslides using the 12 selected strong-motion records according to modified sliding-block method. The critical Newmark displacements $D_{\mathrm{n}, \mathrm{c}}$ for slope failures are assumed as $5 \mathrm{~cm}$ and $10 \mathrm{~cm}$ in rocky (Wieczorek et al., 1985) and soil slopes (Jibson and Keefer, 1993), respectively. The friction angle that corresponds to $D_{\mathrm{n}, \mathrm{c}}$ of $5 \mathrm{~cm} / 10 \mathrm{~cm}$ for JFES/HTP landslides are included in Table 4. According to Table 4, the friction angles at $D_{\mathrm{n}, \mathrm{c}}$ for JFES are mostly higher than those for HTP landslide. On the average, the back-calculated friction angle at JFES is $2.8^{\circ}$ higher than that of the HTP landslide based on 12 records of strong-motion. In Zone III, these differences in friction angles had an average value of $3.5^{\circ}$.

\subsection{Displacement and velocity of sliding block with velocity- dependent friction law}

A Dieterich-Ruina friction law (Scholz, 1998) was incorporated into the modified sliding-block model to calculate the Newmark displacements and velocities of the landslides. The friction coefficient at steady state under a velocity $V$ can be expressed as:

$\mu=\mu_{o}+(a-b) \ln \frac{V}{V_{\mathrm{o}}}$

where $\mu_{\mathrm{o}}$ is the steady-state friction coefficient at a reference velocity $V_{\mathrm{o}}$. Upon initial application of the velocity increase there is an increase $a$ in friction, known as the direct velocity effect. This is followed by an evolutionary effect involving a decrease in friction, of magnitude $b$. The combined friction parameter $(a-b)$ determines the velocity dependency of the steady-state friction. If $(a-b)>0$, friction increases with slip velocity (velocity-strengthening) and the system is stable as more resistance occurs which tends to react against the

Table 4

The calculated friction angle and $(a-b)$ value of the sliding block using the 12 strong-motion records

\begin{tabular}{|c|c|c|c|c|c|c|}
\hline \multirow{2}{*}{$\begin{array}{l}\text { Structural } \\
\text { zone }^{\mathrm{a}}\end{array}$} & \multirow{2}{*}{$\begin{array}{l}\text { Strong-motion } \\
\text { stations }\end{array}$} & \multicolumn{5}{|c|}{ On the sliding direction of the JFES $\left(126 / 21^{\circ}\right) / \mathrm{HTP}\left(330 / 21^{\circ}\right)$ landslides } \\
\hline & & $\begin{array}{l}\text { Friction angle at critical } \\
\text { Newmark displacement } D_{\mathrm{n}, \mathrm{c}}\left({ }^{\circ}\right)\end{array}$ & $\begin{array}{l}\text { Friction angle at the end of } \\
\text { strong ground motion }\left({ }^{\circ}\right)\end{array}$ & $(a-b)$ values & $D_{\mathrm{n}}(\mathrm{m})$ & $\begin{array}{l}\text { Velocity } \\
(\mathrm{m} / \mathrm{s})\end{array}$ \\
\hline \multirow{5}{*}{ Zone I } & TCU065 & $45.4 / 34.1$ & $14.0 / 34.1$ & $-0.0342 /-0.0163$ & $906.2 / 9.2$ & $43.3 / 1.8$ \\
\hline & TCU067 & $34.3 / 33.1$ & $16.1 / 33.1$ & $-0.0176 /-0.0146$ & $1092.3 / 6.8$ & $41.1 / 1.6$ \\
\hline & TCU075 & $27.3 / 26.1$ & $16.8 / 26.1$ & $-0.0096 /-0.0060$ & $1214.2 / 4.8$ & $41.3 / 0.7$ \\
\hline & TCU076 & $29.3 / 31.4$ & $16.7 / 31.4$ & $-0.0117 /-0.0129$ & $1197.0 / 2.9$ & $41.2 / 1.0$ \\
\hline & TCU129 & $37.8 / 32.9$ & $14.8 / 32.9$ & $-0.0227 /-0.0146$ & $1316.8 / 4.1$ & $50.7 / 1.0$ \\
\hline \multicolumn{2}{|c|}{ Average of Zone I } & $34.8 / 31.5$ & $15.7 / 31.5$ & $-0.0192 /-0.0129$ & & \\
\hline \multirow[t]{2}{*}{ Zone II } & TCU071 & $35.2 / 33.3$ & $15.8 / 33.3$ & $-0.0189 /-0.0154$ & $1074.1 / 2.9$ & $42.0 / 0.8$ \\
\hline & TCU072 & $35.0 / 30.7$ & $15.8 / 30.7$ & $-0.0187 /-0.0117$ & $1022.3 / 4.8$ & $41.1 / 0.8$ \\
\hline \multirow[t]{2}{*}{ Zone III } & TCU078 & $31.5 / 28.0$ & $16.6 / 28.0$ & $-0.0141 /-0.0086$ & $1148.4 / 2.1$ & $40.4 / 0.5$ \\
\hline & TCU089 & $28.2 / 25.7$ & $16.2 / 25.7$ & $-0.0110 /-0.0055$ & $1052.4 / 2.9$ & $41.0 / 0.6$ \\
\hline \multicolumn{2}{|c|}{ Average of Zone III } & $31.6 / 28.1$ & $16.2 / 28.1$ & $-0.0146 /-0.0086$ & & \\
\hline \multirow{3}{*}{ Zone IV } & TCU074 & $40.2 / 33.0$ & $12.8 / 33.0$ & $-0.0273 /-0.0164$ & $1243.2 / 1.8$ & $56.7 / 0.8$ \\
\hline & TCU079 & $35.1 / 34.8$ & $14.9 / 34.8$ & $-0.0196 /-0.0176$ & $851.6 / 4.8$ & $40.9 / 0.7$ \\
\hline & TCU084 & $40.9 / 42.9$ & $14.3 / 42.9$ & $-0.0274 /-0.0296$ & $805.1 / 8.8$ & $40.8 / 1.6$ \\
\hline \multicolumn{2}{|c|}{ Average of Zone IV } & $38.7 / 36.9$ & $14.0 / 36.9$ & $-0.0248 /-0.0212$ & & \\
\hline \multicolumn{2}{|c|}{ Average of Zones I, II, III, IV } & $35.0 / 32.2$ & $15.4 / 32.2$ & $-0.0194 /-0.0141$ & & \\
\hline
\end{tabular}

The friction angle of the sliding planes at critical Newmark displacement $D_{\mathrm{n}, \mathrm{c}}$ in the sliding directions of JFES and HTP landslides is calculated where the $D_{\mathrm{n}, \mathrm{c}}$ are assumed as $5 \mathrm{~cm}$ and $10 \mathrm{~cm}$, respectively. The friction angle at the end of strong ground motion, $(a-b)$ values, $D_{\mathrm{n}}$ and velocity at the end of strong ground motion of the Chi-Chi earthquake, are back-calculated using a velocity-dependent friction law.

a The structural zones are shown in Fig. 2. The JFES and HTP landslides are located in Zone III. 

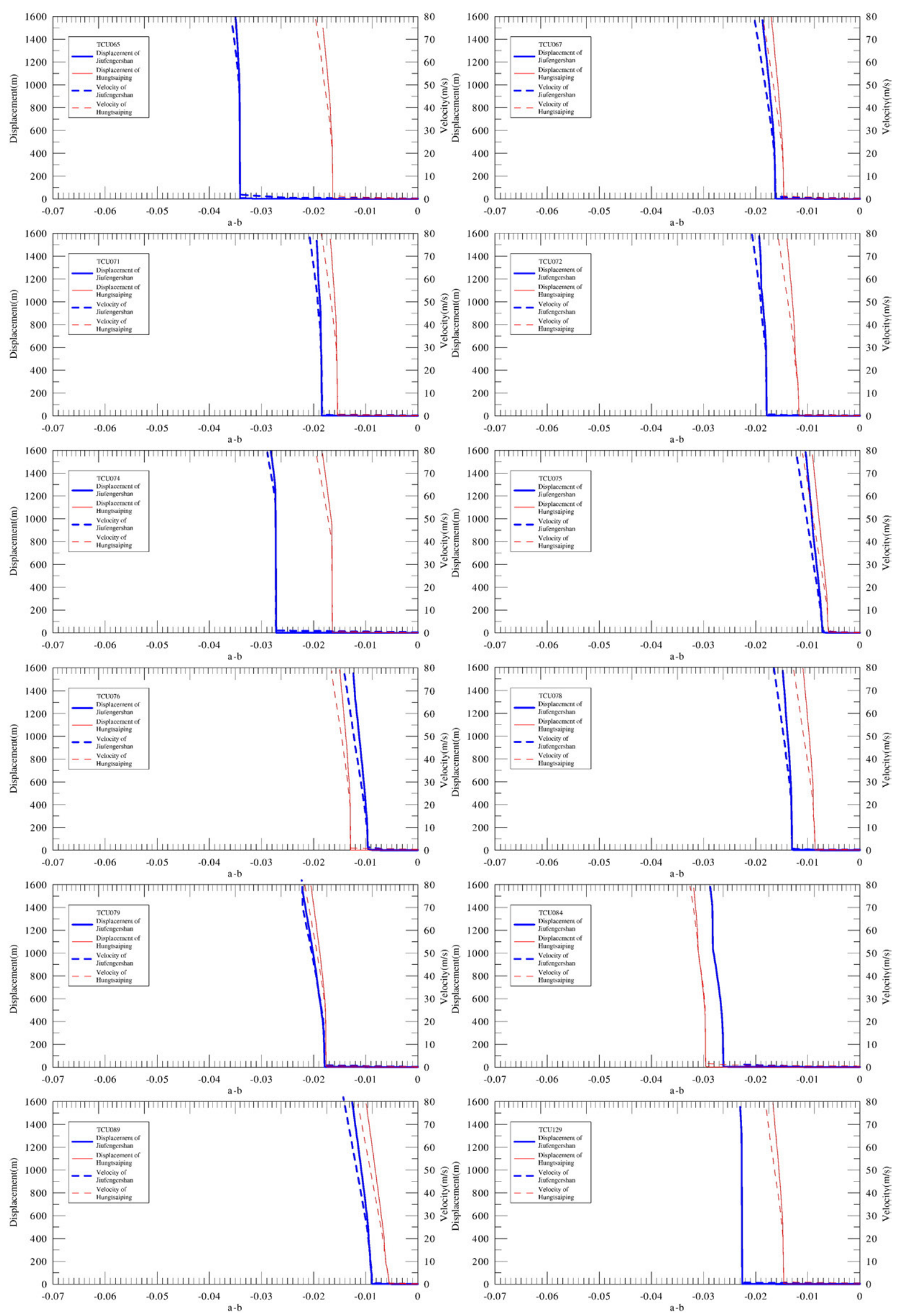

Fig. 11. The calculated Newmark displacements and velocities of sliding blocks in directions of the JFES landslide $\left(126^{\circ} / 21^{\circ}\right)$ and the $\mathrm{HTP}_{\text {landslide }}\left(330^{\circ} / 21^{\circ}\right)$ with different $(a-b)$. The strong-motion records of 12 selected stations during the Chi-Chi earthquake were used. 

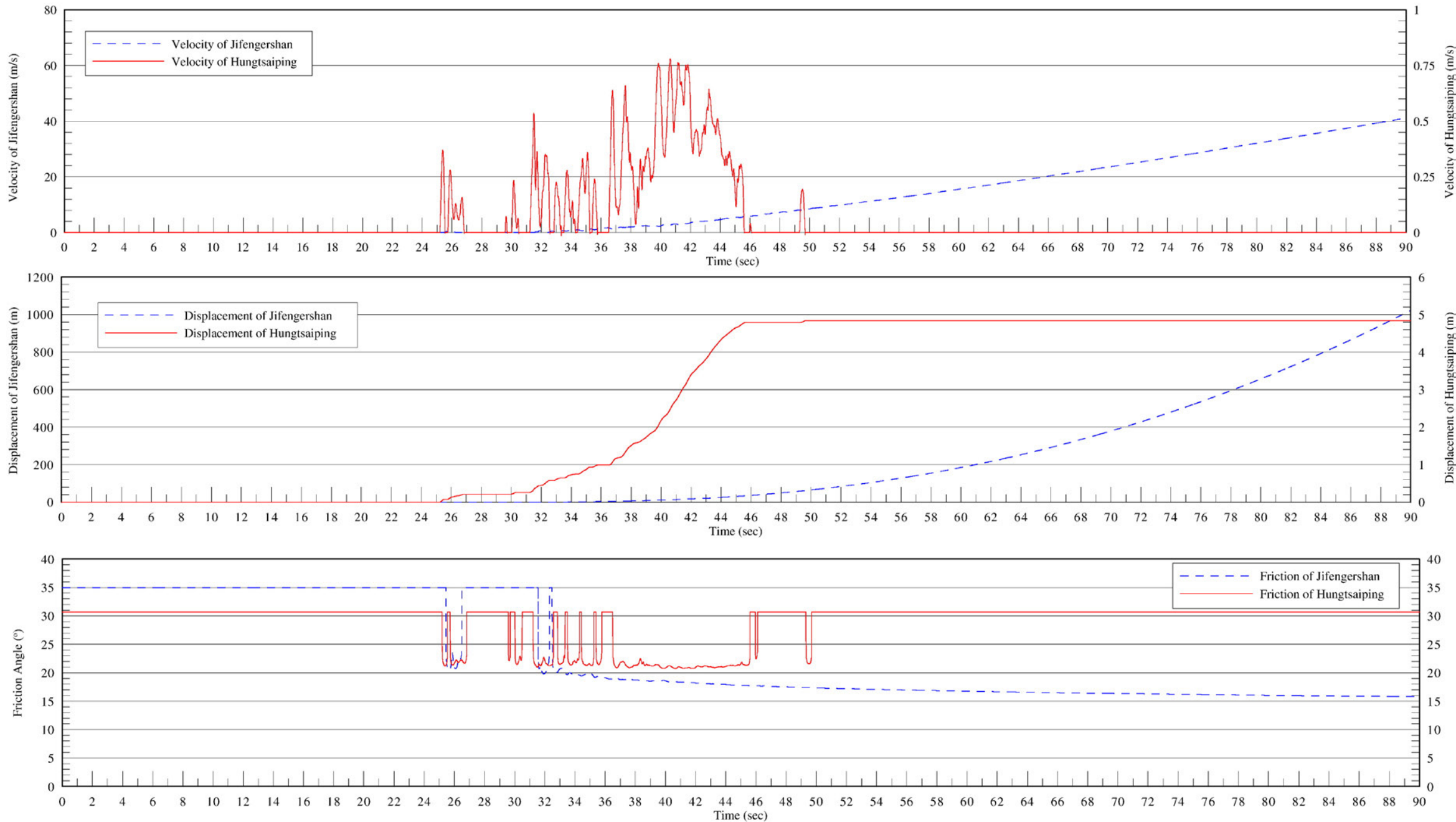

Fig. 12. The Newmark displacements, velocities and friction angles of sliding blocks in directions of (a) the JFES landslide $\left(126^{\circ} / 21^{\circ}\right)$ and (b) the HTP landslide $\left(330^{\circ} / 21^{\circ}\right)$ during the Chi-Chi earthquake based on the records of TCU072. The $(a-b)$ values of the JFES and the HTP landslides were assumed as -0.0187 and -0.0117 , respectively 
increasing velocity. On the other hand, if $(a-b)<0$, friction decreases with slip velocity (velocity-weakening). The friction angle $\phi_{\mathrm{o}}$ of the sliding planes at JFES/HTP landslides that correspond to $D_{\mathrm{n}, \mathrm{c}}$ in Table 4 were used to determine the steadystate friction coefficient $\mu_{\mathrm{o}}\left(=\tan \phi_{\mathrm{o}}\right)$ at a $V_{\mathrm{o}}$ of $0.005 \mathrm{~mm} / \mathrm{min}$ (displacement rate typically used in laboratory tests; Skempton, 1985). The $D_{\mathrm{n}}$ and velocity of sliding block for various friction parameters $(a-b)$ were calculated using the following algorithm.

Critical acceleration is calculated using Eq. ((3) and $\phi_{\mathrm{o}}$. The modified sliding-block method is used to calculate the velocity and $D_{\mathrm{n}}$ at $0.005 \mathrm{~s}$ intervals when the acceleration exceeds a critical value. The velocity at the $i$-th time step is used to compute according to Eq. (4) and derive the critical acceleration at the $(i+1)$-th time step. The procedure is repeated to compute $\mu(=\tan \phi), D_{\mathrm{n}}$ and velocity at $(i+1)$-th time step.

The calculated $D_{\mathrm{n}}$ and velocities of the sliding blocks at JFES/HTP landslides using the 12 selected strong-motion records with different $(a-b)$ are shown in Fig. 11. A critical $(a-b)$ value is identified for the JFES landslide which corresponds to the velocity of sliding mass at $40 \mathrm{~m} / \mathrm{s}$ (averaged sliding velocity of Vaiont landslide is about $20 \mathrm{~m} / \mathrm{s}$, estimated maximum velocity of the JFES landslide is about $80 \mathrm{~m} / \mathrm{s}$ ). For the HTP landslide, the critical $(a-b)$ is chosen when $D_{\mathrm{n}}$ of the sliding mass reached $32 \mathrm{~m}$ (maximum horizontal displacements of the HTP landslide). The critical $(a-b)$ values and at the end of strong-motion duration are included in Table 4.

Based on the strong-motion records of Zone III, the backcalculated friction parameter $(a-b)$ values of the JFES and HTP landslides are -0.0146 and -0.0086 in average (see Table 4), respectively. Thus, the friction angle on the sliding plane for the JFES landslide reduces faster than that of the HTP landslide as the sliding velocity increases. The effects of $(a-b)$ are clearly reflected in the differences of friction angles between the beginning and end of strong ground motion. In the case of JFES landslide the friction angles in Zone III at beginning and end of strong ground motion are $31.6^{\circ}$ and $16.2^{\circ}$, respectively. However, the friction angle at the HTP landslide remains identical at the end of strong ground motion. The back-calculated parameters including $D_{\mathrm{n}}, \phi$, and $(a-b)$ from TCU072 in Zone III are the closest to the average value among the 12 stations. For this reason, the evolution of $\phi, D_{\mathrm{n}}$ and velocity of the sliding block during Chi-Chi earthquake based on the record of TCU072 (located in Zone III) are demonstrated in Fig. 12. The velocity of the JFES increases quickly after about $32 \mathrm{~s}$ and thereafter, the starts to decrease continuously. The calculated maximum velocity of the HTP landslide is only $0.75 \mathrm{~m} / \mathrm{s} \phi$ while of the sliding plane drops temporarily.

\section{Discussion and conclusions}

Intrigued by the close proximity of two large scale Chi-Chi earthquake-induced landslides but with drastically different kinematics, the authors carried out a series of geological and mechanical studies. The JFES landslide can be classified as a rockslide-avalanche where the sliding block traveled a large distance under high velocity. The sliding at HTP occurred mostly in a colluvium with relatively modest displacement. According to the analysis of 12 strong-motion records taken around the subject area during the Chi-Chi earthquake, the horizontal pseudostatic coefficients, earthquake energy ratios, and the Newmark displacements of sliding blocks are all direction-dependent. The influences of the Chi-Chi earthquake are the strongest in the E-W and ESE-WNW trends, perpendicular to the axis of the major geological structures in the area. Because the spatial slip pattern of the Chelungpu fault is locally and regionally tectonically controlled, the rupture behavior of the Chi-Chi earthquake is expected to be repeatable (Ma and Chiao, 2003). The method suggested by Jibson et al. (2000) estimates Newmark displacement based on a regression analysis that considers strength of seismic motion only. This study indicates that in computing the Newmark displacement, the direction-dependent nature of the strong ground motion should also be considered to reflect the tectonic characteristics of the evaluated area.

Using the Kriging interpolation scheme and 12 strongmotion records, comparisons between the JFES and HTP landslides in terms of dimensionless horizontal pseudostatic coefficient, earthquake energy ratio and Newmark displacement were made. Among these three factors, the computed Newmark displacement in the sliding direction of the JFES landslide is larger (44\%) than that of the HTP landslide with plunge of $21^{\circ}$ and friction angle of $28^{\circ}$. We can thus conclude that the seismic anisotropy and the corresponding sliding direction are one of the contributing factors to the kinematics of studied landslides. Apparently, seismic anisotropy, as well as the sliding directions, are important in the occurrence of not only shallow landslides but also large deep-seated landslides. In addition, the selection of representative strong-motion records should consider both the geological similarity as well as proximity to the studied area.

The displaced mass of the HTP landslide is composed of thick colluvial deposits overlaying a thick layer of shale. The displaced mass of the JFES landslide is composed of shale alternating with fine sandstone and siltstone. Both the JFES and HTP landslides belong to Zone III. Based on the strong-motion records in Zones III, the friction angle of sliding surface required to accumulate $5 \mathrm{~cm}$ critical Newmark displacement for the JFES landslide is about $3.5^{\circ}$ higher than that required to accumulate $10 \mathrm{~cm}$ critical Newmark displacement for the HTP landslide.

Rock discontinuities in different materials can have different characteristics of velocity-dependent frictional resistance (Crawford and Curran, 1981). The thick colluvium overlying shale in the HTP landslide area was evidently weaker initially under shaking than the thick sandstone overlying shale of the JFES landslide. Based on the strong-motion records of Zones III, the back-calculated friction parameter $(a-b)$ values producing long-distance rock-avalanche movement of the JFES landslide were less than -0.0146 . On the other hand, the $(a-b)$ was larger than -0.0086 to produce the slow HTP landslide. The friction angle of a sliding plane with smaller $(a-b)$ decreases faster as the velocity increases, and so the friction angle of the colluvium in the HTP landslide was less sensitive to the sliding velocity than was the sliding rock mass of JFES 
landslide. The results indicate that the observed kinematics of the JFES landslide (catastrophic rockslide-avalanche) and the HTP landslide (relatively slow-sliding) are governed at least in part by their velocity-sensitivity in friction resistance. It should be emphasized that the authors did not intend to back calculate the correct friction parameter $(a-b)$ in the velocity-dependent friction law. The main purpose of this research was to demonstrate that the kinematics of two nearby large landslides can be reproduced if friction parameters are properly selected.

In summary, the difference in kinematics between the two nearby large landslides occurred initially due to an earthquake with anisotropic seismic energy. The inherent material behaviors and their discrepancy governed most of the subsequent differences in sliding velocities and displacements. Earlier studies have not reached a consensus on the mechanism of velocity-weakening for slip materials by treating material sliding as a thermo pressurization process (Habib,1975; Goguel,1978; Romero and Molina, 1978; Voight and Faust, 1982; Hendron and Patton, 1985; Tika and Hutchinson, 1999; Chang et al., 2005b). In this paper, the velocity-weakening in frictional resistance was reflected by a much simplified friction parameter $(a-b)$ in a velocity-dependent friction law. The evolution of pore pressure and its effect on the sliding plane was considered implicitly.

Strictly speaking, neither of the sliding surfaces of studied landslides is planar. For the JFES landslide, the rock mass did not daylight. A curved sliding surface must have developed to cut through the rock mass at the toe as hypothesized by many scholars (Huang et al., 2002; Shou and Wang, 2003; Wang et al., 2003a). As for the HTP landslide, it is suspected that the sliding surface was developed along an existing bedding plane which happened to be a contact plane between the colluvium and bedrock. The axis of A Syncline near the toe of the HTP landslide forced the sliding to follow a trend oblique to the dip direction of the bedding plane as well as the maximum peak ground acceleration. The calculated permanent displacement of the sliding block assuming the sliding surface as planar is expected to be higher than the case of a curved sliding surface. However, the influence of the sliding surface curvature on the kinematics of the two studied landslides was not considered in our calculations.

Most of the selected strong-motion stations were located in valleys or on alluvial plains where the subsurface materials are composed of alluvial deposits. It is recognized that the characteristics of strong ground motions depends on the topography and subsurface materials (Kramer, 1996). This research only emphasizes the differences in kinematics of the studied landslides and their corresponding mechanical parameters calibrated from the nearby strong-motion records. The site effect of recorded strong-motion is beyond the scope of this paper.

\section{Acknowledgements}

The work presented in this paper was made possible through the support of the Central Geological Survey, MOEA, Taiwan, ROC. The authors are grateful to Dr. David Keefer for his comments and editing of the manuscript.

\section{References}

Arias, A., 1970. A measure of earthquake intensity. In: Hansen, R.J. (Ed.), Seismic Design for Nuclear Power Plants. Massachusetts Institute of Technology Press, Cambridge, MA, pp. 438-483.

Beeler, N.M., Tullis, T.E., Weeks, J.D., 1994. The roles of time and displacement in the evolution effect in rock friction. Geophys. Res. Lett. 21, 1987-1990

Chang, K.J., Taboada, A., Chan, Y.C., 2005a. Geological and morphological study of the Jiufengershan landslide triggered by the Chi-Chi Taiwan earthquake. Geomorphology 71, 293-309.

Chang, K.J., Taboada, A., Lin, M.L., Chen, R.F., 2005b. Analysis of landsliding by earthquake shaking using a block-on-slope thermo-mechanical model: example of Jiufengershan landslide, central Taiwan. Eng. Geol. 80, 151-163.

Crawford, A.M., Curran, J.H., 1981. The influence of shear velocity on the frictional resistance of rock discontinuities. Int. J. Rock Mech. Min. Sci. Geomech. Abstr. 18, 505-515.

Crespellani, T., Madiai, C., Vannucchi, G., 1998. Earthquake destructiveness potential factor and slope stability. Geotechnique 48, 411-419.

Dieterich, J., 1979. Modelling of rock friction: 1. Experimental results and constitutive equations. J. Geophys. Res. 84, 2161-2168.

Goguel, J., 1978. Scale-dependent rockslide mechanisms, with emphasis on the role of pore fluid vaporization. In: Voight, B. (Ed.), Rockslides and Avalanches, 1. Natural Phenomena. Elsevier, Amsterdam, pp. 693-705.

Habib, P., 1975. Production of gaseous pore pressure during rock slides. Rock Mech. 7, 193-197.

Helmstetter, A., Sornette, D., Grasso, J.R., Andersen, J.V., Gluzman, S., Pisarenko, V., 2004. Slider block friction model for landslides: application of Vaiont and La Clapiere landslides. J. Geophys. Res. 109, B02409. doi:10.1029/2002JB002160.

Hendron, A.J., Patton, F.D., 1985. The Vaiont slide, a geotechnical analysis based on new geologic observations of the failure surface. Technical Report GL-85-5. Department of the Army US Corps of Engineers, Washington, DC.

Huang, C.S., Hsieh, K.S., Chen, M.M., 2000. Explanatory Text of the Geologic Map of Taiwan, 1:50000, Sheet 32, Puli. Published by the Central Geological Survey, Ministry of Economics Affaires.

Huang, C.C., Lee, Y.H., Liu, H.P., Keefer, D.K., Jibson, R., 2001. Influence of surface-normal ground acceleration on the initiation of the Jih-Feng-ErhShan landslide during the 1999 Chi-Chi Taiwan earthquake. Bull. Seismol. Soc. Am. 91, 953-958.

Huang, C.S., Chen, M.M., Hsu, M.I., 2002. A preliminary report on the Chiufenershan landslide triggered by the 921 Chichi earthquake in Nantou, central Taiwan. TAO 13, 387-395.

Hung, J.J., 2000. Chi-Chi earthquake induced landslides in Taiwan. Earthq. Eng. Eng. Seismol. 2 (1), 25-33.

Isaaks, E.H., Srivastava, R.M., 1989. An Introduction to Applied Geostatistics. Oxford University Press.

Jibson, R.W., 1993. Predicting earthquake-induced landslide displacements using Newmark's sliding block analysis. Transp. Res. Rec. 1411, 9-17.

Jibson, R.W., Keefer, D.K., 1993. Analysis of the seismic origin of landslides examples from the New Madrid seismic zone. Geol. Soc. Amer. Bull. 105, 521-536.

Jibson, R.W., Harp, E.L., Michael, J.A., 2000. A method for producing digital probabilistic seismic landslide hazard maps. Eng. Geol. 58, 271-289.

Keefer, D.K., 1984. Landslides caused by earthquakes. Geol. Soc. Amer. Bull. 95, 406-421.

Keefer, D.K., 2000. Statistical analysis of an earthquake-induced landslide distribution - the 1989 Loma Prieta, California event. Eng. Geol. 58, 231-249.

Khazai, B., Sitar, N., 2003. Evaluation of factors controlling earthquake-induced landslides caused by Chi-Chi earthquake and comparison with the Northridge and Loma Prieta events. Eng. Geol. 71, 79-95.

Kramer, S.L., 1996. Geotechnical Earthquake Engineering. Prentice Hall, New Jersey.

Lee, W.H.K., Shin, T.C., Kuo, K.W., Chen, K.C., Wu, C.F., 1999. CWB freefield strong-motion data from the $921 \mathrm{Chi}-\mathrm{Chi}$ earthquake: volume 1. Digital Acceleration Files on CD-ROM.

Lee, W.H.K., Shin, T.C., Kuo, K.W., Chen, K.C., Wu, C.F., 2001a. Data files from CWB free-field strong-motion data from the 921 Chi-Chi (Taiwan) earthquake. Bull. Seismol. Soc. Am. 91, 1370-1376. 
Lee, C.T., Cheng, C.T., Liao, C.W., Tsai, Y.B., 2001b. Site classifications of Taiwan free-field strong-motion stations. Bull. Seismol. Soc. Am. 91, 1283-1297.

Lee, J.F., Wei, C.Y., Huang, C.C., 2004. The study of Hungtsaiping landslide using digital photogrametric technique. Proceeding of International Symposium on Landslide and Debris Flow Hazard Assessment, 2004 Oct 7th-8th, Taiwan, pp. 5-1-5-9.

Liao, H.W., 2000. Landslides triggered by Chi-Chi earthquake. Master's thesis, Institute of Geophysics, National Central University (in Chinese).

Lin, M.L., Tung, C.C., 2003. A GIS-based potential analysis of the landslides induced by the Chi-Chi earthquake. Eng. Geol. 71, 63-77.

Lin, C.W., Shieh, C.J., Yuan, B.D., Shieh, Y.C., Liu, S.H., Lee, S.Y., 2003. Impact of Chi-Chi earthquake on the occurrence of landslides and debris flows: example from the Chenyulan River watershed, Nantou, Taiwan. Eng. Geol. 71, 49-61.

Loh, C.H., Lee, Z.K., Wu, T.C., Peng, S.Y., 2000. Ground motion characteristics of the Chi-Chi earthquake of 21 September 1999. Earthquake Eng. Struc. Dyn. 29, 867-897.

Ma, K.F., Chiao, L.Y., 2003. Rupture behavior of the 1999 Chi-Chi, Taiwan, earthquake-slips on a curved fault in response to the regional plate convergence. Eng. Geol. 71, 1-11.

Newmark, N.M., 1965. Effects of earthquakes on dams and embankments. Geotechnique 15, 139-159.

Parise, M., Jibson, R.W., 2000. A seismic landslide susceptibility rating of geologic units based on analysis of characteristics of landslides triggered by the 17 January, 1994 Northridge, California earthquake. Eng. Geol. 58, 251-270.

Romero, S.U., Molina, R., 1978. Kinematic aspects of the Vaiont slide. Proc. 3rd Congr. Int. Soc. Rock Mech. 2, 865-870.

Ruina, A.L., 1983. Slip instability and state variable friction laws. J. Geophys. Res. 88, 10359-10370.
Scholz, C.H., 1998. Earthquakes and friction laws. Nature 391, 37-42.

Shin, T.C., 2000. Some seismological aspects of the 1999 Chi-Chi earthquake in Taiwan. TAO 11, 555-566.

Shou, K.J., Wang, C.F., 2003. Analysis of the Chiufengershan landslide triggered by the 1999 Chi-chi earthquake in Taiwan. Eng. Geol. 68, 237-250.

Skempton, A.W., 1985. Residual strength of clays in landslides, folded strata and the laboratory. Geotechnique 35, 3-18.

Tika, T.E., Hutchinson, J.N., 1999. Ring shear tests on soil from the Vaiont landslide slip surface. Geotechnique 49, 59-74.

Voight, B., Faust, C., 1982. Frictional heat and strength loss in some rapid landslides. Geotechnique 32, 43-54.

Wang, W.N., Chigira, M., Furuya, T., 2003a. Geological and geomorphological precursors of the Chiu-Feng-Erh-Shan landslide triggered by the Chi-chi earthquake in central Taiwan. Eng. Geol. 69, 1-13.

Wang, W.N., Wu, H.L., Nakamura, H., Wu, S.C., Ouyang, S., Yu, M.F., 2003 b. Mass movements caused by recent tectonic activity: the 1999 Chi-chi earthquake in central Taiwan. Isl. Arc 12, 325-334.

Wei, C.Y., Lee, J.F., 2006. The application of digital aerial photography in the study of Hungtsaiping landslide, Chungliao, Nantou County. Bulletin of the Central Geological Survey 19, 39-59 (in Chinese).

Wen, K.L., Peng, H.Y., Tsai, Y.B., Chen, K.C., 2001. Why 1 g was recorded at TCU129 site during the 1999 Chi-Chi, Taiwan earthquake. Bull. Seismol. Soc. Am. 91, 1255-1266.

Wieczorek, G.F., Wilson, R.C., Harp, E.L., 1985. Map showing slope stability during earthquakes in San Mateo County, California. Miscellaneous Investigation Maps I-1257-E, U.S.G.S.

Yu, S.B., Kuo, L.C., Hsu, Y.J., Su, H.H., Liu, C.C., Hou, C.S., Lee, J.F., Lai, T.C., Liu, C.C., Liu, C.L., Tseng, T.F., Tsai, C.S., Shin, T.C., 2001. Preseismic deformation and coseismic displacement associated with the 1999 Chi-Chi, Taiwan, earthquake. Bull. Seismol. Soc. Am. 91, 995-1012. 